Phylogenetics of Australasian gall flies (Diptera: Fergusoninidae): evolutionary patterns of host-shifting and gall morphology

\author{
S.J. Scheffer ${ }^{1}$, K.A. Davies ${ }^{2}$, G.S. Taylor ${ }^{3}$, A.H. Thornhill ${ }^{4}$, M.L. Lewis ${ }^{1}$, I.S. Winkler ${ }^{5}$, \\ D.K. Yeates ${ }^{4}$, M. F. Purcell ${ }^{6}$, J. Makinson ${ }^{6}$, R.M. Giblin-Davis ${ }^{7}$
}

${ }^{1}$ Systematic Entomology Lab, ARS-USDA, 10300 Baltimore Av., Beltsville, MD 20705. Sonja.scheffer@ars.usda.gov, matthew.lewis@ars.usda.gov

${ }^{2}$ Australian Centre for Evolutionary Biology and Biodiversity, and School of Agriculture, Food and Wine, The University of Adelaide, Waite Campus, PMB 1, Glen Osmond, South Australia 5064, Australia. kerrie.davies@adelaide.edu.au

${ }^{3}$ Australian Centre for Evolutionary Biology and Biodiversity, and School of Biological Sciences, The University of Adelaide, North Terrace, Adelaide, South Australia 5005, Australia.gary.taylor@adelaide.edu.au

${ }^{4}$ CSIRO National Research Collections Australia, PO Box 1700 Canberra, ACT, Australia, 2601. david.yeates@csiro.au

${ }^{5}$ Department of Biology, Cornell College, Mt Vernon, IA 52314. iwinkler@cornellcollege.edu

${ }^{6}$ Australian Biological Control Lab, ARS-USDA, CSIRO Health and Biosecurity, GPO Box2583, Brisbane, Queensland 4068, Australia. Matthew.purcell@csiro.au, jeff.makinson@csiro.au

${ }^{7}$ Fort Lauderdale Research and Education Center, University of Florida, IFAS, 3205 College Avenue, Fort Lauderdale, FL 33314, USA. giblin@ufl.edu 


\begin{abstract}
This study investigated host-specificity and phylogenetic relationships in Australian galling flies, Fergusonina Malloch (Diptera: Fergusoninidae), in order to assess diversity and explore the evolutionary history of host plant affiliation and gall morphology. A DNA barcoding approach using COI data from 203 Fergusonina specimens from 5 gall types on 56 host plant species indicated 85 presumptive fly species. These exhibited a high degree of host specificity; of the 40 species with multiple representatives, each fed only on a single host genus, 29 (72.5\%) were strictly monophagous, and $11(27.5 \%)$ were reared from multiple closely related hosts. COI variation within species was not correlated with either sample size or geographic distance. However variation was greater within oligophagous species, consistent with expectations of the initial stages of hostassociated divergence during speciation. Phylogenetic analysis using both nuclear and mitochondrial genes revealed host genus-restricted clades but also clear evidence of multiple colonizations of both host plant genus and host species. With the exception of unilocular peagalls, evolution of gall type was somewhat constrained, but to a lesser degree than host plant association. Unilocular peagalls arose more often than any other gall type, were primarily located at the tips of the phylogeny, and did not form clades comprising more than a few species. For ecological reasons, species of this gall type are predicted to harbor substantially less genetic variation than others, possibly reducing evolutionary flexibility resulting in reduced diversification in unilocular gallers.
\end{abstract}

Keywords: Fergusonina, multigene phylogeny, host specificity, galling insects, Myrtaceae

Running Title: Diversity and Phylogeny in Fergusonina Flies 
Introduction

The fields of ecology and evolution have the common goals of documenting biodiversity and illuminating the associated ecological patterns and evolutionary history. Plantfeeding insects are a particularly diverse assemblage and often exhibit conspicuous and biologically important ecological characteristics, including host shifts, which potentially affect patterns of diversification (e.g., Mitter et al. 1991; Farrell 1998; Winkler et al. 2009). Comparison of phylogenies from analyses of groups of phytophagous insects and their sister groups has shown that plant-feeding is significantly associated with increased diversity (Mitter et al. 1988).

Host specialization is a common characteristic of plant-feeding insects and appears to be linked to diversity and speciation in these organisms (Janz et al. 2006; but see Novotny et al. 2002). Assessing the degree of host specialization of insect species is an important first step in understanding the ecology and evolution of diet breadth, particularly in the face of abundant seemingly suitable empty niches (Hairston et al. 1960; Strong et al. 1984; Walker and Valentine 1984). To address questions of host specialization, it is necessary to define or delimit the species being studied. Much of the world's biodiversity is currently undescribed, particularly for small, morphologically similar organisms, which includes insects (Purvis and Hector 2000). Unfortunately, defining species is not straightforward; many different criteria and modifications have been proposed over the last 50 years (reviewed in de Queiroz, 2007). It has been suggested that difficulties with fixed species definitions come from the very nature of speciation, that it is often a temporally extended process with different characters evolving at different rates over time (de Queiroz 1998; Dres and Mallet 2002). It has even been argued that "species", in the sense of valid taxonomic and/or evolutionary entities, do not exist (Mishler 2010).

Approaches and methods with the goal of determining species limits have expanded rapidly since the advent of molecular systematics, which has allowed both the 
detection of morphologically cryptic species as well as the assessment of biodiversity in understudied groups (Avise 1994; Scheffer and Wiegmann 2000; Condon et al. 2008). Initially, species delineation was accomplished using a variety of molecular markers (Avise 1994), which could vary depending on the laboratory or taxonomy of the organism being studied. Mitochondrial cytochrome c oxidae subunit I (COI) sequences have proved to be generally useful for species-level analyses in animals (Avise 1994; Scheffer and Wiegmann 2000; Scheffer 2000; Hebert et al. 2003; Meyer and Paulay 2005), although there is abundant empirical and theoretical evidence that COI sequences may not track species evolution and diversification (Funk and Omland 2004; Rubinoff et al. 2006; Song et al. 2008). Nevertheless, COI sequences are widely used to represent a standardized and somewhat universal DNA barcoding identification system for animals, in which sequences are generated for comparison to provide a framework for species identification as well as for large-scale biodiversity assessments (Hebert et al. 2003; Tautz et al. 2003; Janzen et al. 2005; Meyer and Paulay 2005; Pons et al. 2006).

Although a number of methods for species delimitation using DNA barcode data have been developed, a recent study has concluded that a number of such methods do not perform substantially better than the Neighbor-Joining (NJ) $2.0 \%$ divergence cutoff approach used in the early days of species delimitation using mitochondrial COI data (Collins et al. 2012). This should not be surprising, as any system based on a singlemarker can be expected to fail a certain amount of time given the vagarities of molecular evolution, differing taxon-specific biologies, and numerous species concepts. There is broad consensus that using data from multiple sources, such as additional genetic data, ecological traits, or newly detected morphological traits, is preferred in delimitation of species (Pons et al. 2006; Dowton et al 2014; Yeates et al. 2011). Unfortunately, this is not always possible, particularly in the initial studies of diversity in poorly known groups.

In this study we analyzed COI sequence data from an extensive collection of gallforming flies in the monotypic genus Fergusonina Malloch (Diptera: Fergusoninidae) in order to delineate presumptive species (hereafter "species") and determine their host plant affiliations. Associations between genetic variation and the ecological characters of host specificity and geographic distribution are explored. In the second portion of this study, we conducted a phylogenetic analysis of the delineated species using multiple gene 
regions, mitochondrial and nuclear, to explore the evolution of host associations, host specialization, and gall type in these flies.

\section{Study Organisms}

Fergusonina are small morphologically similar flies that feed within galls on various tissues of plants including leaf, shoot bud, and flower buds. All known plant hosts are within the family Myrtaceae (Currie 1937; Tonnoir 1937; Nelson et al. 2014). Galls are formed in conjunction with Fergusobia nematodes (Nematoda: Neotylenchidae) in an obligate mutualism, whereby the nematodes apparently facilitate gall-formation, while the female flies provide dispersal to new gall sites (for details see: Currie 1937; Giblin-Davis et al. 2003, 2004; Davies et al. 2010; Scheffer et al. 2013; Nelson et al. 2014). To date, Fergusonina/Fergusobia galls have been found on seven plant genera of Myrtaceae (Table 1), most notably, eucalypt (Eucalyptus, Corymbia, Angophora) and paperbark (Melaleuca) trees, as well as Leptospermum, Metrosideros, and Syzygium. The mutualism has been found almost exclusively in Australia, with four additional speciespairs known from India, New Guinea, New Zealand, and the Philippines (Harris 1982; Siddiqi 1986, 1994; Taylor et al. 2005; Taylor et al. 2007; Nelson et al. 2014).

From the cumulative morphological and molecular evidence available to date, most fly/nematode associations appear to induce gall formation on a specific host tissue and on a specific host species, although some instances of feeding on multiple hosts are known (Giblin-Davis et al. 2004; Davies and Giblin-Davis 2004; Nelson et al. 2014; Purcell et al. 2016). For example, some widespread eucalypts serve as hosts for multiple pairs of Fergusonina/Fergusobia mutualists (Taylor et al. 2005; Nelson et al. 2014; Purcell et al. 2016). However, a considerable number of fly and nematode species are undescribed (the authors, pers. obs.), making complete and comprehensive fly/nematods/host associations difficult.

Since the initial revision by Tonnoir (1937), most taxonomic work on Fergusonina has been descriptions of one or a few species (e.g., Harris 1982; Taylor et al. 2007; Nelson et al. 2011a, 2011b, 2012), with the exception of Taylor (2004), in which eight species from broad-leafed paperbarks (Melaleuca leucandendra group) were described. In this latter study, each fly species was shown to feed on a single host plant 
species, with the exception of Fergusonina turneri Taylor, which appears to feed on both M. quinquenervia and M. fluviatilis. Molecular analysis of COI/COII sequence data using a $2 \%$ cutoff from 53 members of the broad-leafed paperbark-feeding clade corroborated Taylor's morphological results for seven of the eight species. The sole exception was that the molecular data split $F$. turneri into three host-specific groups: two differing by $3 \%$ on M. fluviatilis and one on M. quinquenervia differing by 4.6-5.1\% to the M. fluviatis groups (Scheffer et al. 2004). Given the morphological similarities of closely related species in the Fergusoninidae, it is not clear whether $F$. turneri represents an oligophagous species feeding on two hosts or a set of monophagous cryptic species. Therefore, this nominal species cannot be used to evaluate the validity of a $2 \%$ delineation cutoff. In any case, all available morphological and molecular data indicate a high level of fly-nematode fidelity and host-plant specificity (Scheffer et al. 2004; Nelson et al. 2014; Purcell et al. 2016).

Taxonomic research on Fergusobia, the nematode mutualists, is ongoing. More than 40 nematode species have been described, generally based on both morphological and molecular findings (Currie 1937; Fisher and Nickle 1968; Siddiqi 1986, 1994; Davies and Lloyd 1996; Davies and Giblin-Davis 2004; Taylor et al. 2007; Taylor and Davies 2008, 2010; Davies et al. 2010a, 2012a, b, 2013a, b, 2014a, b, c, d, e). Molecular phylogenetic analysis of Fergusobia has found considerable specificity and constraint in host use and gall type (Ye et al. 2007).

This study uses DNA-barcoding, in conjunction with a three-gene phylogentic approach, to provide an overall assessment of diversity, host specificity, and evolutionary history in Fergusonina flies.

\section{Materials and Methods}

\subsection{Sampling}

All specimens used in this study were dissected or reared from galls on myrtaceous plant species between 1998 and 2013 (Table 1). Identification of host plant species was accomplished using a variety of taxonomic keys including Brooker and Kleinig (2006), Nicolle (1997, 2006), and Euclid (Brooker et al. 2006). Our samples include specimens from galls on all seven Myrtaceae genera known to host fergusoninids 
(Table 1). In some cases, identifications of Eucalyptus collections were not possible due to the lack of flowers, fruits, or mature leaves, and these species are referred to as " $E$. sp.". Eucalyptus pauciflora s.l., "snow gum", has a number of subspecies, most with very restricted ranges within the wider range of E. pauciflora (Brooker and Kleinig 2006; Nicolle 2006). The high elevation E. niphophila is considered a subspecies of $E$. pauciflora by some authors (Nicolle 2006) and a distinct species by others (Brooker and

Kleinig 2006). In our overall assessment of fergusoninid host specificity, we recognize $E$. niphophila at the rank of species and consider all of the other subspecies to represent $E$. pauciflora s.s.

Galls were classified into broad types based on a modification of the scheme discussed in Nelson et al. (2014) (Table 2). Specifically, galls may be unilocular with a single chamber containing a fly larva or multilocular having as many as several hundred chambers or locules. Multilocular galls most typically involve shoot bud galls, flower bud galls, or expanded leaf blade galls. Unilocular galls often occur in leaf/shoot axils, either sessile or stalked, and resemble a "pea", here referred to as a unilocular peagalls. Unilocular galls also occur on leaf blades either singly or sometimes in a connected row but because these galls could be considered unilocular or multilocular we simply refer to them without locular designation as leaf peagalls (Table 2). We classified galls collected from Syzygium luehmannii as "mix of galls" because these were small unilocular galls on leaves, stems, and buds, which were not separated during rearing.

\subsection{DNA Extraction, PCR, and Sequencing}

Adult, pupal, or larval fergusoninid specimens were stored in $95 \%$ ethanol at -80 C until use. DNA was extracted using the DNeasy Blood and Tissue Kit (Qiagen Inc., Valencia, CA). We amplified and sequenced portions of mitochondrial cytochrome c oxidase subunit I (COI), including the DNA barcode region. We used a $665 \mathrm{bp}$ section of COI from 203 specimens to investigate species limits and 1455 bp, nearly the entire COI region, in the phylogenetic analysis. In addition, we sequenced 799 bp of carbamoyl phosphate synthetase domain (CAD, rudimentary) (Moulton and Wiegmann 2004; Scheffer et al. 2007) and 746 bp of phosphogluconate dehydrogenase (PGD) (Winkler et al. 2009). Primers for both PCR amplification and DNA sequencing are indicated in 
Table 3. Those marked with an asterix are the "standard" primers we used to collect sequence data from all specimens. In cases where additional coverage was deemed necessary, we used additional primers for sequencing in a trial and error approach (Table 3). Variation in ease of data collection was most likely due to sample stage (e.g., small larva vs. adult) and varying collection and storage conditions prior to molecular work.

PCR amplifications for all three gene regions were carried out using Mastercycler Gradient thermocyclers (Eppendorf Scientific, Inc., Westbury, NY, USA) with a touchdown amplification program: initial denaturation at $92{ }^{\circ} \mathrm{C}$ for $2 \mathrm{~min}$, followed by 2 touchdown cycles with annealing temperatures from 58 to $46^{\circ} \mathrm{C}\left(10 \mathrm{~s}\right.$ at $92^{\circ} \mathrm{C}, 10$ s at 58 $46^{\circ} \mathrm{C}, 2 \mathrm{~min}$ at $72^{\circ} \mathrm{C}$ ), 29 cycles of $10 \mathrm{~s}$ at $92^{\circ} \mathrm{C}, 10 \mathrm{~s}$ at $45^{\circ} \mathrm{C}, 2 \mathrm{~min}$ at $72^{\circ} \mathrm{C}$, and a final extension step for $10 \mathrm{~min}$ at $72^{\circ} \mathrm{C}$. Sequencing reactions were carried out using BigDye Sequencing kits (Applied Biosystems, Foster City, CA) and the products were fractionated using ABI377 or ABI3130XL Automated DNA Sequencers (Applied Biosystems). Contigs for each gene from each individual specimen were assembled using the software package Sequencher (Gene Codes, Ann Arbor, MI). Consensus sequences for each gene region were aligned using MUSCLE (Edgar 2004) and then inspected using Se-Al (Rambaut 2002). Alignments were inspected by eye. The COI alignment contained no indels; for PGD we removed a 46 bp region comprising an intron; the CAD alignment contained several deletions uniformly within the ingroup as compared to the outgroups, and these were not removed. Sequences for the three genes were concatenated using Geneious 6.1.3 (Drummond et al. 2009). Outgroups used in the phylogenetic analyses were dipterans in families hypothesized to be related to fergusoninids (Wiegmann et al. 20011): Australimyza sp. (Australimyzidae), Clusia lateralis (Clusiidae), and Xenasteia shalam (Xenastiidae). Outgroup sequences KC177416, KC177428, and KC177433 were retrieved from GenBank; all other sequences have been deposited in GenBank with accession numbers as follows: COI [KY378134-KY378337], CAD [KY378060KY378133], PGD [KY378338-KY378401].

\subsection{Analyses}

Species Delineation 
For species delineation, we used a 665 bp region of the 3' end of COI from all specimens. We chose this region of COI because we have previously found it to be suitably variable for species delimitation in fergusoninids and because its use is consistent with our previous work (Scheffer et al. 2004). We calculated pairwise distances between the sequences using the HKY nucleotide substitution model (Collins et al. 2012). We used the PAUP plug-in within Geneious to construct a Neighbor-Joining tree with 1000 bootstrap pseudoreplicates. Specimens having pairwise distances equal to or less than 2.0 were lumped as a presumptive species. These groups were investigated for monophyly and bootstrap support by visual inspection of the Neighbor-Joining tree.

\section{Host Associations and Gall Type}

Host specificity was assessed for those species for which more than one specimen was present in our dataset. We tested whether monophagous and oligophagous species differed in intraspecific (defined at $2 \%$ ) genetic variability using a t-test on average pairwise distance data. To investigate the relationship of sample size and geographic distance on levels of intraspecific variability, Pearson correlation coefficients were calculated and tested for significance. Correlations were performed first with the combined monophagous and oligophagous dataset and then for each monophagous and oligophagous dataset separately. Geographic distance of samples was considered as the approximate distance $(\mathrm{km})$ between the two most geographically distant samples of any particular species and was estimated using Google Earth (https://www.google.com/earth/). Contingency tables were constructed to explore possible associations between dietary specialization and both host genus and gall type using Chi-Square tests of independence (http://www.socscistatistics.com).

\section{Phylogenetics and Evolution of Host Use}

Phylogenetic analysis of Fergusonina was performed using a 2999 bp concatenated alignment of COI, CAD, and PGD sequences from one representative of each "species" delineated in the COI analysis (see results below). Bayesian and maximum likelihood were used to construct phylogenetic trees. Preliminary analysis of each gene separately found substantial congruence (not shown), and the three genes were 
concatenated for subsequent analyses. Using PartitionFinder2 (Lanfear et al. 2016), analyses were partitioned by gene and assessed for most suitable evolutionary model. In the subsequent analyses, the $\mathrm{GTR}+\mathrm{I}+\mathrm{G}$ model of nucleotide was used for each gene partition. For the Bayesian analysis, we used MrBayes 3.2 on the CSIRO Burnett supercomputer cluster. Analyses were run for 40 million generations to guarantee convergence. Maximum likelihood analysis was performed in the online CIPRES portal using the RAxML Blackbox tool (Miller et al. 2009). Likelihood branch support was also assessed using 1000 rapid bootstraps (Stamatakis et al. 2008) in RAxML v.8.2.0 (Stamatakis 2008), using a general time reversible model with a gamma model of rate heterogeneity, and data partitioned by gene.

Ancestral states for host genus and gall type were reconstructed using parsimony on the MrBayes 50\% majority rule consensus tree using Mesquite v.3.03 (Maddison and Maddison 2015). In order to map characters on a tree that was not fully resolved, a single polytomy was treated as a hard polytomy by Mesquite. Parsimony statistics (consistency index (CI), retention index (RI), and number of steps) for both host genus and gall type separately were also computed in Mesquite in order to compare phylogenetic signal.

\section{Results}

\subsection{Species limits and host-use patterns}

The entire dataset included 203 fly specimens from 56 identified host species, and five gall types collected from sites throughout Australia (Tables 1 and 4, Figure 1). The dataset for assessment of species limits within Fergusonina comprised COI sequences (665 bp COI) from all specimens. Analysis of this dataset resulted in pairwise distances between specimens ranging from 0 to $23 \%$. Application of a monophyly plus $2.0 \%$ maximum dissimilarity threshold resulted in delimitation of 85 presumptive species (Table 4), 43 of which were represented by more than one individual in the NJ analysis (Figure 2). In addition to being monophyletic, 42 had bootstrap support at $90 \%$ or above (37 at 100\%) (Figure 2). With a single exception, all species having multiple representatives formed only a single gall type. The exception was Sp \#57, which was reared from both a shoot bud gall and a flat leaf gall (Table 4). These specimens were both reared from unidentified Eucalyptus species and differed by only $0.3 \%$. 
There were 40 presumptive species of Fergusonina represented by multiple individuals from known hosts (i.e., when "Eucalyptus sp." are excluded). Twenty-nine (72.5\%) were monophagous and 11 (27.5\%) were oligophagous, having been reared from two or more plant species. As many as four closely related host plant species were fed upon by a single species of Fergusonina (Table 5). In all cases, the shared host species were congeneric, and for Eucalyptus-feeders, the shared hosts also belonged to the same Eucalyptus subgenus (Table 5).

Oligophagous species harbored significantly more genetic variation, as measured by average intraspecific pairwise COI distances, than did monophagous species $(\mathrm{t}=-2.93$, $\mathrm{p}<0.006)$. These intraspecific pairwise distance estimates were not significantly correlated with sample size, either in the entire dataset or by level of specialization (Figure 3a, overall $r=0.20, n=40, p>0.20$; monophagous only $r=0.35, n=29, p>0.06$; oligophagous only $r=-0.23, n=11, p>0.40$ ). Similarly, the pairwise distances were not significantly correlated with the maximum intraspecific geographic distance of samples, either when using the full dataset or when the data set was subdivided by degree of dietary specialization (Figure $3 b$, overall $r=0.12, n=40, p>0.20$; monophagous $r=0.23$, $\mathrm{n}=29, \mathrm{p}>0.20$; oligophagous $\mathrm{r}=-0.27, \mathrm{n}=11, \mathrm{p}>0.40$ ).

The genera Corymbia, Eucalyptus and Melaleuca each contained at least one oligophagous species, with Eucalyptus recorded as host to 9 (82\% of all species recorded as oligophagous) (Table 6a). A test of association to determine whether oligophagy occurred significantly more frequently in Eucalyptus than the other genera (combined) was marginally significant (Table 6a, Chi-sq=4.40529, $\mathrm{df}=1, \mathrm{p}=0.044$ ).

Among the oligophagous species of Fergusonina, shoot bud galls were the most common gall type, with 7 (63\%) species forming this gall type. Leaf peagalls, flower bud galls, and unilocular peagalls comprise the remainder (Table 5). There was no association of host specificity and gall type (Table $6 \mathrm{~b}$, Chi-sq=0.1813, $\mathrm{df}=1, \mathrm{p}=0.670$ ).

Individual host plant species served as host to as many as eight species of Fergusonina, although the majority (67\%) were host to only a single species (Table 7). Different species of Fergusonina feeding on the same plant host species often formed galls concurrently on the same plant individual. In most cases, the galls were of different types and in different tissues, although in several instances galls of different species on 
the same host plant were of the same type and sometimes indistinguishable (Table 7). It was often possible to recognize the different species of Fergusonina dissected from these indistinguishable galls by their larval morphology (in third instar), and also by differences in the morphologies of the associated Fergusobia nematodes (when diagnosable stages are present).

\subsection{Phylogenetics and host use evolution}

Maximum likelihood and Bayesian analysis of the concatenated COI, CAD, and PGD dataset found the monophyletic Fergusonina to be highly divergent from the outgroups. Within the Fergusoninidae, considerable conservation of host-use was apparent $(\mathrm{CI}=0.67, \mathrm{RI}=0.88$, steps=9; Figures 4, 5). Most major clades of Fergusonina were reared from only a single host plant genus (Figure 5), and in all of the 25 cases of "sister" taxa (regardless of pairwise distance), both species shared the same host plant genus or subgenus (Figure 4).

There was a deep split between the few samples reared from Syzygium and the other plant hosts. Most notably, 41 (89\%) out of the 46 species of Fergusonina reared from eucalypts were found within two large clades restricted to Eucalyptus. Although these had little bootstrap support, they contained well-supported Eucalyptus-feeding subclades. Fergusoninids on the two subgenera of Eucalyptus included in this study, Eucalyptus and Symphyomyrtus, also exhibited patterns of host-restriction. The 13 specimens from the subgenus Eucalyptus formed two well-supported clades (excluding two fly specimens from undetermined Eucalyptus spp.), one sister to a clade of Symphyomyrtus gallers and one nested within a clade of Symphyomyrtus gallers (Figure 5). Melaleuca-feeding fergusoninids formed two distinct host-associated clades: one well-supported clade on the monophyletic broad-leaved Melaleuca group, and a second small clade from three narrow-leaved species of Melaleuca (Figures 5).

In the ancestral state reconstruction of host plant affiliation, the identity of the ancestral host was ambiguous, being either Eucalyptus or Syzygium (Figure 5). Subsequent nodes were clearly associated with Eucalyptus (Subgenus Symphyomyrtus). All remaining fergusoninids formed a large clade associated with a mix of host genera, but the polytomy at the base of this clade precludes ancestral host reconstruction. 
However, within the clade, host-associated lineages are present. Association with Melaleuca appears to have evolved once, with a subsequent divergence into a primarily broad-leaf Melaleuca clade (one narrow-leaf exception) and a lineage comprised of a narrow-leaf Melaleuca clade sister to a clade of six species exhibiting unusually diverse feeding habits: four gall types on three host genera (Figure 5).

Host shifts to Corymbia-feeding likely evolved three times (Figure 5). Approximately half of the eight or so species that feed on Corymbia formed a highly supported monophyletic clade, while the remaining species were present in two wellsupported clades each of which contained species from more than one host genus. These two small "mixed" clades, one of which was sister to the narrow-leaved melaleucas, above, were the only well-supported clades to involve shifts between host plant genera (Figure 5).

Oligophagous Fergusonina species were distributed across the phylogeny, but were significantly overrepresented in the $\mathrm{C}+\mathrm{D}$ clade (Figure 5). Approximately $55 \%$ (6 of 11) of the oligophagous species were present in this clade of 17 species. In contrast, only 5 of the remaining 67 species in the phylogeny were oligophagous, a highly significant difference in distribution of oligophagy across the phylogeny (Table 6c, Chi-sq=19.01, $\mathrm{df}=1, \mathrm{p}<0.0001 ;$ Figure 5).

The evolution of gall type exhibited a moderate degree of conservation on the Fergusonina phylogeny $(\mathrm{CI}=0.25, \mathrm{RI}=0.66$, steps $=16)$, although less than did host affiliation (Figure 5). All gall types appear to have evolved at least twice, with unilocular peagalls having arisen as many as seven times (Figure 5). Most species of Fergusonina were embedded within clades of various sizes consisting of the same gall type. In 23 of 25 cases of supposed sister taxa (regardless of distance), both species shared the same gall type (Figure 5).

There appeared to be no relationship between shifts to new plant genera and the evolution of a new gall type (Figure 5). Of 68 resolved nodes in the phylogeny, ancestral reconstructions indicated that only two nodes involved both a shift to a new genus and the acquisition of a new gall type (black dots in Figure 5). However, in both cases, the shift in the fly and the shift in the nematode were not in the same direction. At the upper node, the shift in host affiliation involved a host shift from Melaleuca to Corymbia on 
branch A. From the same node there was a shift in gall type, from shoot bud galls to unilocular peagalls on branch B (Figure 5). Although the two shifts in host affiliation and gall types occurred from the same node, the shifts occurred in different lineages (A vs. B branches) and did not correspond with each other. The second set of black dots indicates another case of apparently associated changes in host affiliation (Eucalyptus subgenus Symphyomyrtus to subgenus Eucalyptus) and changes in gall type. As in the previous case, careful inspection showed that the changes did not occur on the same branches $(\mathrm{C}$ vs. D) and, therefore, did not correspond (Figure 5).

The clade containing Melaleuca may contain two additional co-associated shifts in plant host and gall type, but without resolution of the basal polytomy and reconstruction of the characters, the status of potential nodes was unclear (Figure 5).

\section{Discussion}

In recent years, morphological and ecological investigations of fergusoninid flies and their nematode mutualists have made clear that substantial diversity awaits discovery in these unusual organisms (Taylor 2005: Taylor et al. 2007; Scheffer et al. 2004; Ye et al. 2007; Davies et al. 2010, 2016; Nelson et al. 2011a, 2011b, 2012, 2014; Purcell et al. 2013, 2016). Our present analysis of COI sequence data from 203 Fergusonina specimens representing five gall types and seven host genera has resulted in the delimitation of 85 putative species, approximately 19 of which correspond to one of the 38 named Fergusonina species (Table 7, see Nelson et al. 2014).

As is typical of most endophagous phytophagous insects, we found fergusoninids to be quite host-specific. Of the 43 presumptive species represented in our study by more than one individual, $100 \%$ fed only on a single genus, while $73 \%$ were strictly monophagous, feeding on a single host plant species. However, this is undoubtedly an underestimate of monophagy. First, two of 11 oligophagous species are classified here as oligophagous depending on whether E. niphophila is considered distinct from $E$. pauciflora. If these were each considered to represent a single host species, the reclassification of two oligophagous species of Fergusonina into four monophagous species would increase the estimate of monophagy from $73 \%$ to $83 \%$. Second, our estimate of specialization does not consider the 42 species represented in this study by 
only a single fly specimen. Most specimens in this study were collected in the presence of many potential host plant species. This is particularly true for samples from Eucalyptus, which is an extremely widespread genus of over 700 species, most of which are found in sympatry with other species of Eucalyptus. Simply put, Fergusonina species have substantial ecological opportunity for oligophagous associations, and researchers in the field have ample opportunity for collecting them on more than one host. We suggest that host-plant specialization of fergusoninids is considerably greater than appears here.

In contrast to general expectations, intraspecific genetic variation was not correlated with either sample size (ranging from $n=2$ to15) or geographic distance of samples (ranging from 0 to $3000 \mathrm{~km}$ ) in any of the analyses; this is true whether using the entire dataset or subdivisions based on host specificity (Figure 4). This indicates, that in terms of sampling, our $2 \% \mathrm{COI}$ distance criterion was largely robust to variation in sample size and geographic distance, such that it was reasonably suitable for delimitation of putative species. However, without multiple lines of evidence, the accuracy of our COI approach to species delimitation remains to be rigorously tested.

Although there appeared to be no significant relationship between genetic variation and either sample size or geographic distance, genetic variation did differ with host specialization. Oligophagous species harbored significantly more genetic variation than monophagous species ( $\mathrm{t}=-2.93, \mathrm{p}<0.006$; see values in Table 4). Within phytophagous insects, it is not uncommon for what appear to be oligophagous species to represent diverging or recently diverged cryptic species (e.g., Fox and Morrow 1981; Blair et al. 2005; Scheffer and Hawthorne 2007; Nosil 2012). Genetic adaptation to different host plants could lead to what appears to be increased intraspecific genetic variation when both host-associated populations are regarded as a single species. Our results are consistent with a scenario involving increased genetic variation arising from processes of host plant associated divergence within oligophagous species. Interestingly, oligophagous species were disproportionately represented in clade $\mathrm{C}+\mathrm{D}$ (Figure 5), indicating a propensity for either acquiring and/or maintaining this habit within this clade. Further exploration of oligophagy within Fergusonina, along with the genetics and ecology of associated host-use characters, is likely to shed light on processes of diversification and uncover substantial cryptic diversity. 


\section{Phylogenetics}

Phylogenetic analysis found the Syzygium feeders to be sister to the clade encompassing all of the other fergusoninids (Figure 5). To date, flies from Syzygium in Australia have only been found from a single location on the Atherton Tablelands of the Wet Tropics in Far North Queensland, despite considerable search efforts targeting Syzygium in other locations within Australia. An additional fergusoninid, F. syzygii, was previously described from Syzygium in India but no specimens were available for this study. Syzygium is widespread in southeastern Asia, and it is likely that additional fergusoninid species will be found on this genus in this region. Whether additional Fergusonina on Syzygium are affiliated with those in the current tree forming the sister group to all the other Fergusonina is unknown, but has important implications for our understanding of the origin, early host use, and diversification of these flies.

The evolutionary history of host-use by fergusoninids on the other genera of Myrtaceae is one of considerable genus-level conservation; most species of Fergusonina belonged to large host restricted clades (Figures 5,6), indicating that once a host genus or subgenus is colonized, the descendant species typically remain on hosts within that genus or subgenus. However, with the exception of Leptospermum gallers $(n=2)$ fergusoninids were not found to be strictly monophyletic on any host genera or Eucalyptus subgenera, indicating some degree of colonization and host switching at the level of plant genus.

Feeding on Eucalyptus appears to be the ancestral state for the main lineage of Fergusonina (Figure 5). A single host shift from Eucalyptus to other genera in an large unresolved polytomy is likely to represent one of only two host shifts away from Eucalyptus. The second shift involves only a single species (FC-79 in Figure 5) and is from Eucalyptus to Corymbia. All species of Fergusonina feeding on the Eucalyptus subgenus Eucalyptus formed three distinct clades (Figure 5, yellow boxes), one imbedded within and one sister to clades feeding on the subgenus Symphyomyrtus, with the third encompassing the clade containing the shift from Eucalyptus to Corymbia (Figure 5).

Fergusonina feeding on Melaleuca also exhibit an evolutionary history of hostconservation. In the host plant reconstruction, the fergusoninids feeding on Melaleuca came out in a single clade within which a shift to Corymbia occurred (Figure 5, node A- 
B) resulting in two Melaleuca subclades. The largest fed almost exclusively on the monophyletic broad-leaved paperbark group with the single exception of one species on $M$. nodosa, a narrow-leaved form. The second smaller clade $(\mathrm{n}=3)$ was monophyletic on narrow-leaved Melaleuca species (Figures 4, 5). Despite the small number of Corymbiafeeding samples in this study, the reconstruction indicated that this host genus has been colonized at least three times (Figure 5).

The high degree of plant host conservation of the majority of Fergusonina clades suggests that host shifts during speciation in Fergusonina occur under considerable evolutionary constraint. The notion of evolutionary constraints has a long history in evolutionary biology and encompasses various conditions of genetic variation, efficacy of selection, and evolutionary stasis (reviewed by Futuyma 2010; Futuyma and Agrawal 2009). Heritable genetic variation is necessary for evolutionary change (Falconer and Mackey1989); an absence of such variation in a particular character constrains evolution in that character. For example, an insect species may lack the genetic variation necessary for evolutionary change in a character, such as the ability to feed on plant A, but possess the genetic variation needed to shift to plant B. Over evolutionary time, a host shift by this species to plant B would be more likely than to plant A (Futuyma et al. 1993, 1995; Scheffer 1999; Uesugi 2008). This is simultaneously a constraint on evolutionary change to host A as well as a preferential shift to host B.

That host constraints and preferential host shifting are a large component of hostuse evolution in the fergusoninids is apparent not only in the high level of host genus conservation in the phylogeny, but also by the observation that none of the 25 sister lineages identified in the phylogeny involve a shift to a new host genus. Some of the splits between these sister lineages are quite deep and probably do not represent recent speciation events; that there appear to be no host genus shifts even at these older nodes reinforces the conclusion that host shifts at the genus level are rare. More dramatically, the fact that no fergusoninids have successfully shifted to plants beyond the Myrtaceae serves to highlight their propensity for evolutionary constraint in host affiliation.

In this study, 18 of the 64 plant species served as host to more than one fergusoninid species (Table 5). In most cases, the fergusoninids sharing a host produced different types of gall and were rarely sister species, indicating repeated recolonization of 
host plant species (Figure 5). This is in contrast to some other galling insects (Cook et al. 2002; Joy and Crespi 2007) that appear to radiate into different gall niches following colonization of a single host species. The greatest number of Fergusonina/Fergusobia species has been found on the most widespread host plant species - E. camaldulensis (4 species, 3 gall types) and E. pauciflora (6 species, 3 gall types) (Table 5). These host species have broad geographic ranges, thus presenting more opportunity for colonizations by fergusoninids. However, such widespread distributions also made it more likely that we encountered and sampled these plants. Whether the level of diversity in fergusoninids and associated nematodes seen on these host plants reflects a general pattern remains to be seen.

The evolution of gall type in fergusoninids showed varying degrees of evolutionary constraint across the fly phylogeny (Figure 6). In only two of 25 cases of "sister" species was there a difference in gall type, indicating that shifts are not especially frequent. Several large clades of flies reared from a single gall type can be seen in the phylogeny (Figure 5). Character reconstruction of gall type across the phylogeny suggests that essentially all shifts in gall type involved shifts from shoot bud gallers, the sole exception being a leaf peagaller arising from a flower bud galler (FC-113, FC-173). All five of our defined gall types have evolved multiple times (Figure 5). In fact, the six species forming the clade designated as A (Figure 5) exhibit four of the five gall types.

Although the evolution of gall type appears to be somewhat labile, with multiple instances of all gall types, future sub-classification of gall types may indicate less lability, in the sense of less convergence in gall type, than appears here (see Purcell et al. 2016). For example, the site of galling within flower buds differs in which tissue is actually galled, e.g., ovaries vs. stamens (Giblin-Davis et al. 2004), but this type of fine-scale data were not collected for all galls in the study so we treated all flower bud types as one category. Subdivision of the leaf peagall (one vs. several locules) category and the unilocular peagall (axillary vs. stalked) might also prove useful. It could be that, in some cases, what appears to be multiple origins of the same gall type across the phylogeny may instead represent the evolution of novel gall sub-types following recolonization of broad categories of host tissues for oviposition. In Fergusonina, it seems that oviposition typically takes place while the host tissue is in the early bud stage (Giblin-Davis et al. 
2004). Although buds may ultimately give rise to different tissues, it may be that at the time of oviposition, the buds for different host tissues represent fairly similar targets for female flies, setting the stage for an evolutionary shift in gall type. Analysis of the microfeatures of galls and their reconstruction across Fergusonina, Fergusobia, and host plant phylogenies could greatly impact our current view of gall type lability in this mutualism.

An additional feature of Fergusonina possibly relevant to the evolution of gall type is interspecific variation in a morphological character known as the larval dorsal shield. This is a conspicuous structure on the fly larvae of sclerotized (hardened) bumps, ridges, plates, and, in some cases, dramatic hooks of unknown function and not present in any other Diptera (Currie 1937, Taylor et al. 2005; Taylor and Davies 2010; Purcell et al. 2016). The presence of thick mucus near the dorsal shield, often associated with nematodes, suggests a possible secretory role (Currie 1937; Davies et al. 2016; David Merritt, pers. obs.). In addition, the dorsal shield may be used to anchor the fly larva within the gall cavity while feeding or to scrape the internal wall of the gall chamber to enlarge it and/or to stimulate the proliferation of fresh gall tissue on which the larva and/or nematodes feed (Taylor et al. 2005; Taylor and Davies 2010). However, the dorsal shields of some fergusoninid species seemingly lack characters useful for scraping. A recent study has shown that individual clades of fergusoninids share the same dorsal shield morphology (Purcell et al. 2016), indicating that additional exploration of all aspects of the dorsal shield is important to understanding Fergusonina/Fergusobia biology and host plant interactions.

For the Fergusoninidae, the intimate and obligate relationship between the flies and their associated nematodes undoubtedly adds a layer of complexity to the mechanisms involved with shifting onto new host species or new host tissues (gall types) in this mutualism. Unlike all other phytophagous insects, female fergusoninids carry nematodes that are deposited during each fly oviposition. Gall formation on a new host necessarily requires survival of both the fly larvae and the Fergusobia nematodes as galls lacking either one of the mutualists have not been found (nor yet generated in the lab).

Obviously, the initial stage of a host range expansion or a host shift in Fergusonina/Fergusobia depends on the behavior of the female fly as she determines 
which novel host plants and/or host tissues are used for oviposition. Because the nematodes are responsible for gall formation, they are critical to the success of the initial stages of a host shift; the nematodes must be able to survive and perform on the new host. If the nematodes die or perform poorly, the offspring of the female fly will also die or perform poorly. The outcome of these processes, i.e., whether a shift occurs or not, depends to a large extent on the levels of genetic variation for these traits within both the fly and nematode populations.

In the case of the Fergusobia nematodes, which essentially have no "free-living" stage, effective population sizes are likely to vary depending on the locularity of the galls (Nelson et al. 2014). Large multilocular galls can have multiple, conspecific, fly foundresses (Purcell et al. 2015), probably allowing mating among nematodes deposited by multiple female flies into a single gall. Such panmixia of conspecific nematodes should maintain some degree of genetic variation within nematode species in these larger galls. In contrast, nematodes within unilocular galls, those having an isolated, single chamber, must be restricted to extreme inbreeding via mating between siblings multiple generations. In addition, a large portion of the nematode population in unilocular gallers is lost each generation when they are deposited along with a Fergusonina egg destined to be male (adult male flies do not carry nematodes, Scheffer et al. 2014). These Fergusobia are predicted to harbor low levels of genetic variation causing limited evolutionary flexibility. Due to the critical role played by Fergusobia nematodes in gall formation (and probably other functions), the genetic effects of long-term inbreeding may reduce the ability of the entire mutualism to withstand environmental or other challenges, thus leading to increased extinction and possibly constraining speciation.

The highly inbred mating system of unilocular galling nematodes may cause their genetic structure to be very similar to that of asexual species. A classic case of the apparent effect of lack of genetic variation on evolutionary flexibility is that of asexual organisms. On theoretical grounds, the origin of asexuality is often considered to be advantageous (Williams 1975; Maynard Smith 1978), and asexuality can be found in many animal lineages (Bell 1982; Schwander and Crespi 2009). However, asexuality may also have a cost in that genetic variation is lost, deleterious mutations accumulate, and population-wide recombination does not produce new genotypes (Maynard Smith 
1978). These consequences may prevent a species from moving into new resources and adapting to new environmental challenges. This implies that although asexuality may arise not uncommonly, the lineages do not persist and/or form large clades (but see Schwander and Crespi 2009). Under this scenario, asexuality should be most often associated with recent shallow lineages at the tips of the phylogenies, but not with older and larger clades.

Phylogenetic analysis of Fergusonina shows that the evolutionary history of unilocular peagall formation is similar to that of asexuality. On the fergusoninid phylogeny, unilocular peagalls show a pattern consistent with repeated origins and reduced diversification: there are seven independent origins of unilocular peagallers with no more than three extant species in any clade. In contrast, flowerbud gallers appear to have originated five times, with one of the clades containing eight species (plus a shift to a leaf peagall), while the other major gall types have evolved three times or fewer. The seven lineages of unilocular peagallers are found throughout the phylogeny, indicating that this gall type has arisen in multiple major lineages (Figures 4, 5). Why this gall type has arisen more frequently than others is a puzzle. Genetic variation aside, it seems as though the small size of this gall type would make the occupants more susceptible to a variety of ecological challenges such as increased parasitism by hymenopterans, less protection from dramatic changes in climate, and substantially smaller population sizes (for review of advantages, see Price et al. 1983; Stone and Schönrogge 2003). However, at this point we know very little of the ecological and genetic aspects of Fergusobia. Further phylogenetic and population genetic investigations of both Fergusonina and Fergusobia mutualists will be necessary to address the possible impact of gall-associated life history differences in diversification in this mutualism.

Currently, we know little regarding the initial shift or origin of Fergusonina and Fergusobia on Myrtaceae; neither contemporary Fergusonina nor their nematode mutualists, Fergusobia, appear to have close relatives that might shed light on ancestral hosts and feeding modes, and the mutualistic association itself is unique (Giblin-Davies et al. 2003, 2004; Wiegmann et al. 2011; Nelson et al. 2014). In general, galling insects are disproportionately overrepresented in xeric habitats, where galls serve to provide constant humidity, in addition to protection from natural enemies and nutrition 
(Fernandez and Price 1992; Price et al. 1998). Australia has become increasingly xeric over the past 20 million years (Byrne et al. 2008), possibly contributing to the radiation of Fergusonina/Fergusobia (Nelson et al. 2014). Additional work comparing history of the Australian climate and biota along with timing and topologies of the Fergusonina, Fergusobia, and Myrtaceae host plant diversifications is underway and expected to shed light on diversification of this mutualism.

\section{Conclusion}

Our study has focused on evolutionary history of Fergusonina and its association with host plants in the Myrtaceae. We found that diversity and patterns of host-associated radiations in this group primarily reflect plant taxon-constrained host shifting such that host shifts associated with speciation most often involved closely related plants. This pattern was not only seen in the conservation of host genus and subgenus in the phylogeny, but is also consistent with the observation that fergusoninids have not successfully colonized any other plant family nor even most genera within the Myrtaceae. Sister species (based on current phylogeny) of Fergusonina fed only on congeneric hosts, and the hosts of oligophagous species were also closely related plant species. The oligophagous species contained more genetic variation than the specialists, consistent with oligophagy as an early stage of host-constrained and host-associated speciation.

The evolution of gall type also exhibited some evolutionary constraint across the fly phylogeny, but to a lesser degree than host plant genus. Unilocular peagalls originated more times than any other gall type, but were found primarily at the tips of the phylogeny. It may be that the evolution of unilocular gall type is advantageous in some unknown way, but that reduced genetic variation in the Fergusobia nematodes associated with this gall type, impairs evolutionary flexibility, speciation, and/or persistence.

Fergusonina and Fergusobia are part of a more complex network of interactions involving parasitic relationships between the mutualism and the host plants. In contrast to the flies feeding on the host plants, for many gall forms the Fergusobia nematodes are vertically transmitted across fly generations, thus raising the expectation of cospeciation between at least some lineages of Fergusonina and Fergusobia. Further investigation of the phylogenetics of these mutualists, as well as their host plants, will shed light on the 
roles played by cospeciation, host-shifting, and evolutionary constraint in determining current patterns.

\section{Acknowledgements}

The authors thank Kevin Omland at the University of Maryland Baltimore County, Leigh Nelson at the Australian National Insect Collection, Adam Cardilini at Deacon University, and Ted Center at the USDA IPRL (Invasive Plant Research Lab) in Fort Lauderdale, Florida for their help and support in lab and field studies. Some of the research summarized in this article was supported by USDA Special Grants in Tropical and Subtropical Agriculture (CRSR-99-34135-8478 and CRSR-03-34135-14078) to RGD; and by Australian Biological Resources Survey grants to KAD, and a CSIRO McMaster Fellowship to SJS. Mention of trade names or commercial products in this publication is solely for the purpose of providing specific information and does not imply recommendation or endorsement by the USDA; USDA is an equal opportunity provider and employer.

\section{Figure Legends}

Figure 1. Collecting locations in Australia. Each dot represents a location where samples were collected. Colors indicate genera of hosts from which samples were collected.

Figure 2. Neighbor-Joining consensus of $665 \mathrm{bp}$ of COI for species delimitation. Species for which more than one individual is in the study are shown in blue with plant host(s) shown. Light blue denotes monophagous species, dark blue indicates oligophagous species, and a black circle indicates a singleton representative. Bootstrap values shown below branches of monophagous and oligophagous species. Height of triangles reflects sample size. 
Figure 3. Relationship between average pairwise distance and a) sample size of each species, and b) maximum geographic distance within each species. Both datasets analyzed three ways: 1) All species in dataset, 2) Monophagous species only, 3) Oligophagous species only. Bonferroni correction for multiple (six) tests requires significance criterion of $\mathrm{p}<0.05$ be reduced to $\mathrm{p}<0.008$.

Figure 4. Bayesian analysis of relationships among Fergusonina species. Posterior probabilities above 0.95 indicated above branches while likelihood bootstrap values indicated below. Colors designate genus affiliations, while gall type is shown as cartoon representations (see Table 2). Red circles indicate nodes with descendants categorized here as "sister" species (see Methods).

Figure 5. Character state reconstruction of host plant affiliation (on left) and gall type (on right) using the topology of the Bayesian tree that is presented in Figure 4. Code names of oligophagous species indicated by blue rectangles. Eucalyptus subgenus Eucalyptus contained in yellowish boxes. Remaining Eucalyptus belong to subgenus Symphytomyrtus. In this figure, unidentified Eucalyptus species were drawn as belonging to the subgenus of their sister species or clade. Black branch in the Plant Host Genus tree on the left indicates an ambiguity???? in the host reconstruction. Clades A, B, C, D, and black circles denote regions of the trees discussed in the text (Results, Discussion).

\section{References}

Avise, J.C., 1994. Phylogeography: The History and Formation of Species. Harvard Univ. Press, Harvard, MA.

Bell, G., 1982. The Masterpiece of Nature. The Evolution and Genetics of Sexuality. University of California Press, Berkeley, California.

Blair, C.P., Abrahamson, W.G., Jackman, J.A., Tyrrel, L., 2005. Cryptic speciation and host-race formation in a purportedly generalist tumbling flower beetle. Evol. 59: 304-316. 
Brooker, M.I.H., Kleinig D.A., 2006. Field Guide to Eucalypts, Vol. 1: South-Eastern Australia, $3^{\text {rd }}$ ed. Blooming Books, Melbourne, Australia.

Brooker, M.I.H., Slee, A.V., Connors, J.R., 2006. EUCLID Eucalypts of southern Australia, 3rd edition, CD. CSIRO Publishing, Collingwood, Australia.

Byrne, M., Yeates, D. K., Joseph, L., Kearney, M., Bowler, J., Williams, M.A.J., Cooper, S., Donnellan, S.C., Keogh, J.S., Leys, R., Melville, J., Murphy, D.J., Porch, N., Wyrwoll, K.-H., 2008. Birth of a biome: insights into the assembly and maintenance of the Australian arid zone biota. Mol. Ecol. 17: 4398-417.

Collins, R.A., Boykin, L.M., Cruickshank, R.H., Armstrong, K.F., 2012. Barcoding's next top model: an evaluation of nucleotide substitution models for specimen identification. Methods in Ecology and Evolution 3: 457-465. doi: 10.1111/j.2041210X.2011.00176.x

Condon, M.A., Scheffer, S.J., Lewis, M.L., Swensen, S.M., 2008. Hidden neotropical diversity: greater than sum of its parts. Sci. 320: 928-931. doi: 10.1126/science.1155832

Cook, J.M., Rokas, A., Pagel, M., Stone, G.N., 2002. Evolutionary shifts between host oak sections and host-plant organs in Andricus gallwasps. Evol. 56: 1821-1830.

Currie, G.A., 1937. Galls on Eucalyptus trees. A new type of association between flies and nematodes. Proc. Linn. Soc. New South Wales 62: 147-174.

Davies, K.A., Giblin-Davis, R.M., 2004. The biology and associations of Fergusobia (Nematoda) from the Melaleuca leucadendra-complex in eastern Australia. Invert. Syst. 18: 291-319.

Davies, K.A., Lloyd, J., 1996. Nematodes associated with Diptera in South Australia: a new species of Fergusobia Currie and a new record of Syrphonema Laumond \& Lyon. Trans. R. Soc. S. Australia 120: 13-20.

Davies, K.A., Ye, W., Giblin-Davis, R., Taylor, G.S., Thomas, W.K., 2010. Nematodes from galls on Myrtaceae. I. Fergusobia/Fergusonina galls on Corymbia spp., with redescription of $F$. magna and notes on its phylogenetic relationships. Zootaxa 2634: 2540.

Davies, K.A., Ye, W., Giblin-Davis, R., Taylor, G.S., Thomas, W.K., 2012a. Nematodes from galls on Myrtaceae. II. Fergusobia/Fergusonina from small axillary bud ('stem') and leaf ('pea') galls in Australia, with descriptions of two new species. Zootaxa 3415: 122. 
Davies, K.A., Ye, W., Giblin-Davis, R., Taylor, G.S., Thomas, W.K., 2012b. Nematodes from galls on Myrtaceae. III. Fergusobia from flower bud and stigma galls on Eucalyptus, with descriptions of four new species. Zootaxa 3532: 1-36.

Davies, K.A., Ye, W., Giblin-Davis, R., Taylor, G.S., Thomas, W.K., 2013a. Nematodes from galls on Myrtaceae. IV. Fergusobia from flat leaf galls on Eucalyptus and Corymbia, with descriptions of two new species. Zootaxa 3741: 151-171.

Davies, K.A., Ye, W., Giblin-Davis, R., Taylor, G.S., Thomas, W.K., 2013b. Nematodes from galls on Myrtaceae. V. Fergusobia from large multilocular shoot bud galls from Angophora and Eucalyptus in Australia, with descriptions of five new species. Zootaxa 3741: 101-140.

Davies, K.A., Giblin-Davis, R.M., Ye, W., Taylor, G.S., Hodda, M., Thomas, W.K., 2014a. Nematodes from galls on Myrtaceae. VII. Fergusobia from 'leafy' leaf bud galls, with re-description of Fergusobia tumifaciens (Currie 1937) Wachek 1955 and descriptions of two new species. Zootaxa 3856: 529-554.

Davies, K.A., Taylor, G.S., Nelson, L.A., Yeates, D., Giblin- Davis, R.M., 2014 b. Nematodes from galls on Myrtaceae. VI. Fergusobia from galls on Angophora in Australia, with description of $F$. colbrani n. sp. and key. Zootaxa 3856: 326-348.

Davies, K.A., Bartholomaeus, F., Giblin-Davis, R.M., Ye, W., Taylor, G.S., Thomas, W.K., 2014c. Nematodes from galls on Myrtaceae. VIII. Fergusobia from small galls on shoot buds, with descriptions of four new species. Zootaxa 3857: 1-40.

Davies, K.A., Ye, W., Giblin-Davis, R., Taylor, G.S., Thomas, W.K., 2014d. Nematodes from galls on Myrtaceae. IX. Fergusobia rosettae n. sp. on Melaleuca quinquenervia and F. tolgaensis n. sp. on Syzygium luehmannii, from Queensland. Zootaxa 3889: 214-236.

Davies, K.A., Bartholomaeus, F., Giblin-Davis, R.M., Ye, W., Taylor, G.S., Thomas, W.K., 2014e. Nematodes from galls on Myrtaceae. X. Fergusobia from galls on narrowleaved Melaleuca spp. in Australia, with descriptions of three new species. Zootaxa 3889: 237-258.

Davies, K., Ye, W., Giblin-Davis, R., Taylor, G., Scheffer, S., Thomas, W., 2010a. The nematode genus Fergusobia (Nematoda: Neotylenchidae): molecular phylogeny, descriptions of clades and associated galls, host plants and Fergusonina fly larvae. Zootaxa 2633: 1-66.

De Queiroz, K. 1998. The general lineage concept of species, species criteria, and the process of speciation: a conceptual unification and terminological recommendations, in: Howard, D.J., Berlocher, S.H. (Eds.) Endless Forms: Species and Speciation, Oxford Univ. Press, Oxford, UK. 
De Queiroz, K., 2007. Species Concepts and Species Delimitation. Syst. Biol. 56: 879886. doi: $10.1080 / 10635150701701083$

Dowton, M., Meiklejohn, K., Cameron, S.L., Wallman, J., 2014. A preliminary framework for DNA barcoding, incorporating the multispecies coalescent. Systematic Biology, 63: 639-644.

Drès, M., Mallet, J., 2002. Host races in plant-feeding insects and their importance in sympatric speciation. Phil. Trans. R. Soc. B Biol. Sci. 357: 471-492.

Drummond, A. J., Ashton, B., Cheung, M., Heled, J., Kearse, M., Moir, R., Wilson, A., 2009. Geneious R7.

Drummond AJ, Rambaut A., 2007. BEAST: Bayesian evolutionary analysis by sampling trees. BMC Evol. Biol. 7:214.

Edgar, R.C., 2004. MUSCLE: multiple sequence alignment with high accuracy and high throughput. Nucleic Acids Research 32, 1792-1797.

Falconer, D.S., Mackay, T.F.C., 1996. Introduction to Quantitative Genetics, $4^{\text {th }}$ edition. Pearson, 480pp.

Farrell, B.D., 1998. "Inordinate fondness" explained: why are there so many beetles? Sci. 281: 555-559.

Fernandez, G.W., Price, P.W., 1992. The adaptive significance of insect gall distribution: survivorship of species in xeric and mesic habitats. Oecol. 90: 14-20.

Fisher, J.M., Nickle, W.R., 1968. On the classification and life history of Fergusobia curriei (Sphaerulariidae: Nematoda). Proc. Helminth. Soc. Wash. 35: 40-46.

Fox, L.R., Morrow, P.A., 1981. Specialization: species property or local phenomenon? Sci. 211: 887-893.

Funk, D.J., Omland, K.E., 2004. Species-level paraphyly and polyphyly: frequency, causes, and consequences, with insights from animal mitochondrial DNA. Ann. Rev. Ecol. Evol. 34: 397-423.

Futuyma, D.J., 2010. Evolutionary constraint and ecological consequences. Evol. 64: $1865-1884$.

Futuyma, D.J., Agrawal, A.A., 2009. Macroevolution and the biological diversity of plants and herbivores. PNAS 106: 18054-18061.

Futuyma, D.J., Keese, M.C., Funk, D.J., 1995. Genetic constraints on macroevolution: the evolution of host affiliation in the leaf beetle genus Ophraella. Evol. 49: 797-809. 
Futuyma, D.J., Keese, M.C., Scheffer, S.J., 1993. Genetic constraints and the evolution of insect-plant associations: responses of Ophraella communa (Coleoptera: Chrysomelidae). Evol. 47: 888-905.

Giblin-Davis, R.M., Center, B.J., Davies, K.A., Purcell, M.F., Scheffer, S.J., Taylor, G.S., Goolsby, J., Center, T.D., 2004. Histological comparisons of

Fergusobia/Fergusonina-induced galls on different myrtaceous hosts. J. Nematol. 36: 249-262.

Giblin-Davis, R.M., Makinson, J., Center, B.J., Davies, K.A., Purcell, M., Taylor, G.S., Scheffer, S.J., Goolsby, J., Center, T.D., 2001. Fergusobia/Fergusonina-induced shoot bud gall development on Melaleuca quinquenervia. J. Nematol. 33: 239-247.

Giblin-Davis, R.M., Scheffer, S.J., Davies, K.A., Taylor, G.S., Curole, J., Center, T.D., Goolsby, J., Thomas, W.K., 2003. Coevolution between Fergusobia and Fergusonina mutualists. Nematol. Monogr. Persp. 2: 1-11.

Hairston, N.N., Smith, F.E., Slobodkin, L.B., 1960. Community structure, population control, and competition. Am. Nat. 94: 421-425.

Harris, K.M., 1982. First record of Fergusoninidae (Diptera: Schizophora) outside Australia: a new species of Fergusonina on Syzygium in India. Syst. Entomol. 7: 211216.

Hartl, D.L., Clark, G.C., 1997. Principles of Population Genetics, $3^{\text {rd }}$ ed. Sinauer Associates, Sunderland, MA.

Hebert P. D. N., Cywinska A., Ball S. L., DeWaard J. R., 2003. Biological identifications through DNA barcodes. Proc. R. Soc. B 270:313-321.

Janz, N., Nylin, S., Wahlberg, N., 2006. Diversity begets diversity: host expansions and the diversification of plant-feeding insects. BMC Evol. Biol. 6. doi:10.1186/14712148-6-4.

Janz, N., Nylin, S., 2008. The Oscillation Hypothesis of Host-Plant Range and Speciation.

Janzen, D.H., Hajibabaei, M., Burns, J.M., Hallwachs, W., Remigio, E., Hebert, P.D., 2005. Wedding biodiversity inventory of a large and complex Lepidoptera fauna with DNA barcoding. Phil. Trans. R. Soc. B Biol. Sci. 360: 1835-1845.

Joy, J.B., Crespi, B.J., 2007. Adaptive radiation of gall-inducing insects within a single host-plant species. Evol. 61: 784-795. 
Lanfear, R., Frandsen, P. B., Wright, A. M., Senfeld, T., Calcott, B., 2016.

PartitionFinder 2: new methods for selecting partitioned models of evolution for molecular and morphological phylogenetic analyses. Mol. Biol. Evol. DOI: dx.doi.org/10.1093/molbev/msw260

Maddison, W.P., Maddison, D.R., 2015. Mesquite: A modular system for evolutionary analysis. Version 3.03. http://mesquiteproject.org

Maynard Smith, J., 1978. The Evolution of Sex. Cambridge University Press, Cambridge, UK. 236 pp.

Mishler, B.D., 2010. Species are not uniquely real biological entities. 'Contemp. Debates Philos. Biol.’ (Eds F Ayala, R Arp) pp. 110-122. Wiley-Blackwell.

Mitter, C., Farrell, B., Futuyma, D.J., 1991. Phylogenetic studies of insect-plant interactions: insights into the genesis of diversity. TREE 6: 290-293.

Mitter, C., Farrell, B., Wiegmann, B., 1988. The phylogenetic study of adaptive zones: has phytophagy promoted insect diversification? Am. Nat.132:107-128.

Meyer, C.P., Paulay, G., 2005. DNA barcoding: error rates based on comprehensive sampling. PLOS Biol. http://dx.doi.org/10.1371/journal.pbio.0030422

Moulton, J. K., Wiegmann B.M., 2004. Evolution and phylogenetic utility of CAD (rudimentary) among Mesozoic-aged eremoneuran Diptera (Insecta). Mol. Phylogenet. Evol. 31: 363-378.

Nelson, L.A., Davies, K.A., Scheffer, S.J., Taylor, G.S., Purcell, M.F., Giblin- Davis, R.M., Thornhill, A.H., Yeates, D.K., 2014. An emerging example of tritrophic coevolution between flies (Diptera: Fergusoninidae) and nematodes (Nematoda: Neotylenchidae) on Myrtaceae host plants. Biol. J. Linn. Soc. 111: 699-718.

Nelson, L. A., Scheffer, S. J., Yeates, D. K., 2011a. Two new species of sympatric Fergusonina Malloch flies (Diptera: Fergusoninidae) from bud galls on high-elevation snow gums (Eucalyptus pauciflora Sieb. ex Spreng. complex) in the Australian Alps. Australian Journal of Entomology, 50: 356-364.

Nelson, L. A., Scheffer, S. J., Yeates, D. K., 2011b. Three new species of Fergusonina Malloch gall-flies (Diptera: Fergusoninidae) from terminal leaf bud galls on Eucalyptus (Myrtaceae) in south-eastern Australia. Zootaxa 3112: 36-48

Nelson, L. A., Scheffer, S. J., Yeates, D. K., 2012. Species diversity of Fergusonina Malloch gall flies (Diptera: Fergusoninidae) forming leaf bud galls on snow gum (Eucalyptus pauciflora Sieb. ex Spreng. complex), with a description of a new species from Tasmania. Insect Systematics \& Evolution 43: 147-160. 
Newman, D., Pilson, D., 1997. Increased probability of extinction due to decreased genetic effective population size: experimental populations of Clarkia pulchella. Evol. 51: 354-362.

Nicolle, D., 1997. Eucalypts of South Australia. Published by D. Nicolle

Pub., Morphett Vale, S.A., Australia, 208 pp.

Nicolle, D., 2006. Eucalypts of Victoria and Tasmania. Bloomings Books, Melbourne, Australia. $310 \mathrm{pp}$.

Nieminen, M., Singer, M.C., Fortelius, W., Schops K., Hanski, I., 2001. Experimental confirmation that inbreeding depression increases extinction risk in butterfly populations. Am Nat 157:237-244

Novotny, V., Basset, Y., Miller, S.E., Weiblen, G.D., Bremer, B., Cizek, L. and Drozd, P., 2002. Low host specificity of herbivorous insects in a tropical forest. Nature 416: 841844.

Pons, J., Barraclough, T.G., Gomez-Zurita, J., Cardoso, A., Duran, D.P., Hazell, S., Kamoun, S., Sumlin, W.D. and Vogler, A.P., 2006. Sequence-based species delimitation for the DNA taxonomy of undescribed insects. Systematic Biology, 55: 595-609.

Price, P.W., Fernandes, G.W., Lara, A.C.F., Brawn, J., Barrios, H., Wright, M.G., Ribero, S.P., Rothcliff, N., 1998. Global patterns in local number of insect galling species. J. Biogeog. 25: 581-591.

Price, Peter W., G. Wilson Fernandes, and Gwendolyn L. Waring. "Adaptive nature of insect galls." Environmental Entomology 16.1 (1987): 15-24.

Purcell, M.F., Rowell, D.M., Yeates, D.K., 2015. Are the shoot bud galls of Fergusonina Malloch, 1924 (Diptera: Fergusoninidae) founded by multiple mothers? Austral. Entomol. 54: 286-291.

Purcell, M.F., Nelson, L.A., Thornhill, A.H., Yeates, D.K., 2013. Two new species of Fergusonina Malloch gall fly (Diptera: Fergusoninidae) from leaf bud galls on black sallee (Eucalyptus stellulata) and manna gum (Eucalyptus viminalis). Austral. Entomol. 52, 363-370. doi:10.1111/aen.12044.

Purcell, M.F., Wallenius, T.C., Yeates, D.K., Rowell, D.M., 2016. Larval dorsal shield morphology is highly correlated with gall type in the enigmatic gall-forming fly, Fergusonina Malloch (Diptera : Fergusoninidae). Austral. J. Zool.

Purvis A., Hector, A., 2000. Getting the measure of biodiversity. Nature 405: 212-219.

Rambaut A (2002) Sequence Alignment Editor (Se-Al) v2.0. http://tree.bio.ed.ac.uk/software/seal/. 
Regier, J.C., 2008. Protocols, Concepts, and Reagents for preparing DNA sequencing templates. Version 12/4/08. www.umbi.umd.edu/users/jcrlab/PCR_primers.pdf.

Rubinoff, D., Cameron, S. and Will, K., 2006. A genomic perspective on the shortcomings of mitochondrial DNA for "barcoding" identification. J. Heredity, 97: 581594.

Scheffer, S.J., 1999. Genetic variation and the potential for host range evolution in the leafmining fly Amauromyza flavifrons (Diptera: Agromyzidae). Ann. Ent. Soc. Am. 92: 742-747.

Scheffer, S.J., 2000. Molecular evidence of cryptic species within the Liriomyza huidobrensis (Diptera: Agromyzidae). J. Econ. Entomol. 93:1146-1151.

Scheffer, S.J., Giblin-Davis, R.M., Taylor, G.S., Davies, K.A., Purcell, M., Lewis, M.L., Goolsby, J., Center, T.D., 2004. Phylogenetic relationships, species limits, and host specificity of gall-forming Fergusonina flies (Diptera: Fergusoninidae) feeding on Melaleuca (Myrtaceae). Ann. Ent. Soc. Am. 97: 1216-1221.

Scheffer, S.J., Hawthorne, D.J., 2007. Molecular evidence of host-associated genetic divergence in the holly leafminer Phytomyza glabricola (Diptera: Agromyzidae): apparent discordance among marker systems. Molec. Ecol. 16: 2627-2637. http://doi.org/10.1111/j.1365-294X.2007.03303.x

Scheffer, S.J., Nelson, L.A., Davies, K.A., Lewis, M.L., Giblin-Davis, R.M., Taylor, G.S., Yeates, D.K., 2013. Sex-limited association of Fergusobia nematodes with female Fergusonina flies in a unique Australasian mutualism (Nematoda: Neotylenchidae; Diptera: Fergusoninidae). Austr. J. Entomol. 52: 125-128. doi:10.1111/aen.12013

Scheffer, S.J., Wiegmann, B.M., 2000. Molecular phylogenetics of the holly leafminers (Diptera: Agromyzidae: Phytomyza): species limits, speciation, and dietary specialization. Mol. Phylogenet. Evol. 17: 244-255.

Scheffer, S.J., Winkler, I.S., Wiegmann, B.M., 2007. Phylogenetic relationships within the leaf-mining flies (Diptera: Agromyzidae) inferred from sequence data from multiple genes. Mol. Phylogenet. Evol. 42: 756-775.

Schwander, T., Crespi, B.J., 2009. Twigs on the tree of life? Neutral and selective models for integrating macroevolutionary patterns with microevolutionary processes in the analysis of asexuality. Molec. Ecol., 18: 28-42. doi:10.1111/j.1365-294X.2008.03992.x

Scott, M.J., Kriticou, D., Robinson, A.S., 1993. Isolation of cDNAs encoding 6phosphogluconate dehydrogenase and glucose-6-phosphate dehydrogenase from the Mediterranean fruit by Ceratitis capitata: correlating genetic and physical maps of chromosome 5. Insect Mol. Biol. 1: 213-222. 
Siddiqi, M.R., 1986. A review of the genus Fergusobia Currie (Hexatylina) with descriptions of F. jambophila n. sp. and F. magna n. sp., in: Swarup, G., Dasgupta, D.R., (Eds.) Plant Parasitic Nematodes of India, Problems and Progress. New Delhi, India. pp. 264-278.

Siddiqi, M.R., 1994. Fergusobia brevicauda, sp.n. and F. philippinensis, sp.n. (Nematoda: Hexatylina) from Eucalyptus deglupta. Proceedings of the Second AfroAsian Nematology Symposium, 18-22 December 1994. Afro-Asian Society of Nematologists, Cairo, Egypt, 96-100.

Simon, C., F. Frati, F., Beckenbach, A., Crespi, B., Liu, H., Flook, P., 1994. Evolution, weighting, and phylogenetic utility of mitochondrial gene sequences and a compilation of conserved polymerase chain reaction primers. Ann. Entomol. Soc. Am. 87: 651-701.

Song, H., Buhay, J.E., Whiting, M.F. and Crandall, K.A., 2008. Many species in one: DNA barcoding overestimates the number of species when nuclear mitochondrial pseudogenes are coamplified. PNAS 105: 13486-13491.

Stamatakis, A., 2008. RAxML version 8: a tool for phylogenetic analysis and postanalysis of large phylogenies. Bioinformatics 30:1312-1313.

Stamatakis, A., Hoover, P. and Rougemont, J., 2008. A rapid bootstrap algorithm for the RAxML web servers. Syst. Biol. 57:758-771.

Stone, Graham N., and Karsten Schönrogge. "The adaptive significance of insect gall morphology." Trends in Ecology \& Evolution 18.10 (2003): 512-522.

Strong, D.R., Lawton, J.H., Southwood, S.R., 1984. Insects on Plants: Community Patterns and Mechanisms. Harvard Univ. Press, Cambridge, MA, 313 pp.

Tautz, D., Arctander, P., Minelli, A., Thomas, R.H., Vogler, A.P., 2003. A plea for DNA taxonomy. Trends Ecol. Evol. 18: 70-74.

Taylor, G.S., 2004. Revision of Fergusonina Malloch gall flies (Diptera: Fergusoninidae) from Melaleuca (Myrtaceae). Invert. Syst. 18: 251-290.

Taylor, G.S., Davies, K.A., 2008. New species of gall flies (Diptera: Fergusoninidae) and an associated nematode (Tylenchida: Neotylenchidae) from flower bud galls on Corymbia (Myrtaceae). Austr. J. Entomol. 47: 336-349.

Taylor, G.S., Davies, K.A., 2010. The gall fly, Fergusonina lockharti Tonnoir (Diptera: Fergusoninidae) and description of its associated nematode, Fergusobia brittenae sp. nov. (Tylenchida: Neotylenchidae). J. Nat. Hist. 44: 927-957.

Taylor, G.S., Davies, K., Martin, N., Crosby, T., 2007. First record of Fergusonina (Diptera: Fergusoninidae) and associated Fergusobia (Tylenchida: Neotylenchidae) 
forming galls on Metrosideros (Myrtaceae) from New Zealand. Syst. Entomol. 32: 548557.

Taylor, G.S., Head, E., Davies, K.A., 2005. Gall flies (Diptera: Fergusoninidae) on Myrtaceae: a mutualistic association between flies and nematodes, in: Rahman, A., Schaefer, C.W., Withers, T.M. (Eds.) Biology, Ecology and Evolution of Gall-Inducing Arthropods, Vol. 2, Science Publishers, New Hampshire, U.S., pp. 643-671.

Tonnoir, A.L., 1937. Revision of the genus Fergusonina Mall. Proc. Linn. Soc. NSW 62: 126-146.

Uesugi, A., 2008. Evolution of host avoidance in a leafmining fly, Amauromyza flavifrons. Entomol. Exp. Appl. 128:398-402.

Walker, T.D., Valentine, J.W., 1984. Equilibrium models of evolutionary species diversity and the number of empty niches. Am. Nat. 124: 887-899.

Wiegmann, B.M., Trautwein, M.D., Winkler, I.S., Barr, N.B., Kim, J., Lambkin, C., Bertone, M.A., Cassel, B.K., Bayless, K.M., Heimberg, A.M., Wheeler, B.M., Peterson, K.J., Pape, T., Sinclair, B.J., Skevington, J.S., Blagoderov, V., Caravas, J., Kutty, S.N., Schmidt-Ott, U., Kampmeier, G.E., Thompson, F.C., Grimaldi, D.A., Beckenbach, A.T., Courtney, G.W., Friedrich M., Meier, R., Yeates, D.K., 2011. Episodic radiations in the fly tree of life. PNAS 108: 5690-5695.

Williams, G.C., 1975. Sex and Evolution. Princeton Univ. Press, Princeton, NJ.

Winkler, I.S., Rung, A., Scheffer, S.J., 2010. Hennig's orphans revisited: testing morphological hypotheses in the "Opomyzoidea" (Diptera: Schizophora). Mol. Phylog. Evol. 54: 746-762.

Winkler, I. S., Scheffer, S. J., Mitter, C., 2009. Molecular phylogeny and systematics of leaf-mining flies (Diptera: Agromyzidae): delimitation of Phytomyza Fallen sensu lato and included species groups, with new insights on morphological and host-use evolution. Syst. Ent. 34: 260-292. http://doi.org/10.1111/j.1365-3113.2008.00462.x

Ye, W., Giblin-Davis, R.M., Davies, K.A., Purcell, M., Scheffer, S.J., Taylor, G.S., Center, T.D., Morris, K., Thomas, W.K., 2007. Molecular phylogenetics and the evolution of host plant associations in the nematode genus Fergusobia (Tylenchida: Fergusobiinae). Mol. Phyl. Evol. 45: 123-141.

Yeates, D.K., Seago, A., Nelson, L., Cameron, S.L., Joseph, L., Trueman, J.W.H., 2011. Integrative taxonomy, or iterative taxonomy? Syst. Ent. 36: 209-217 


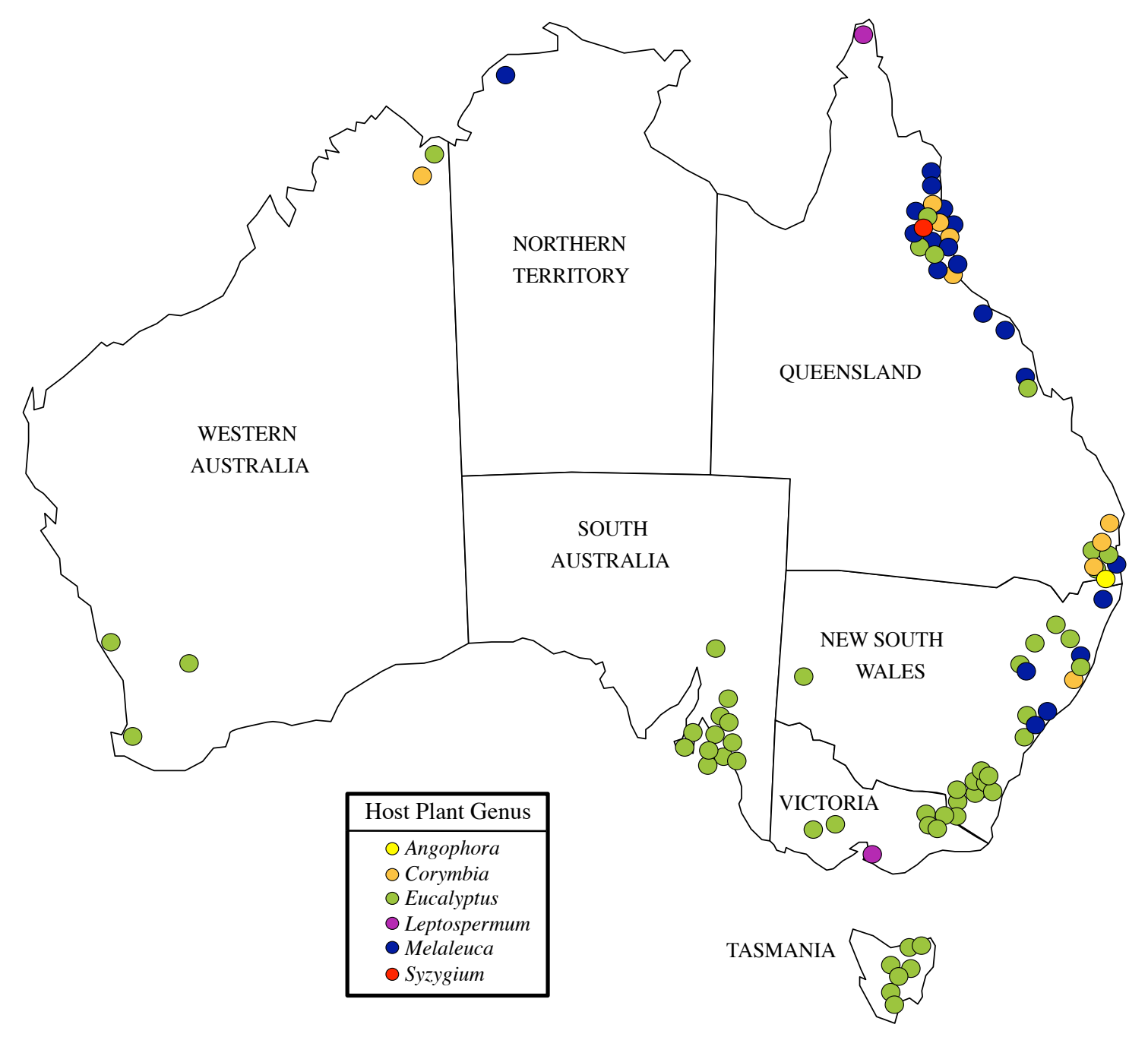




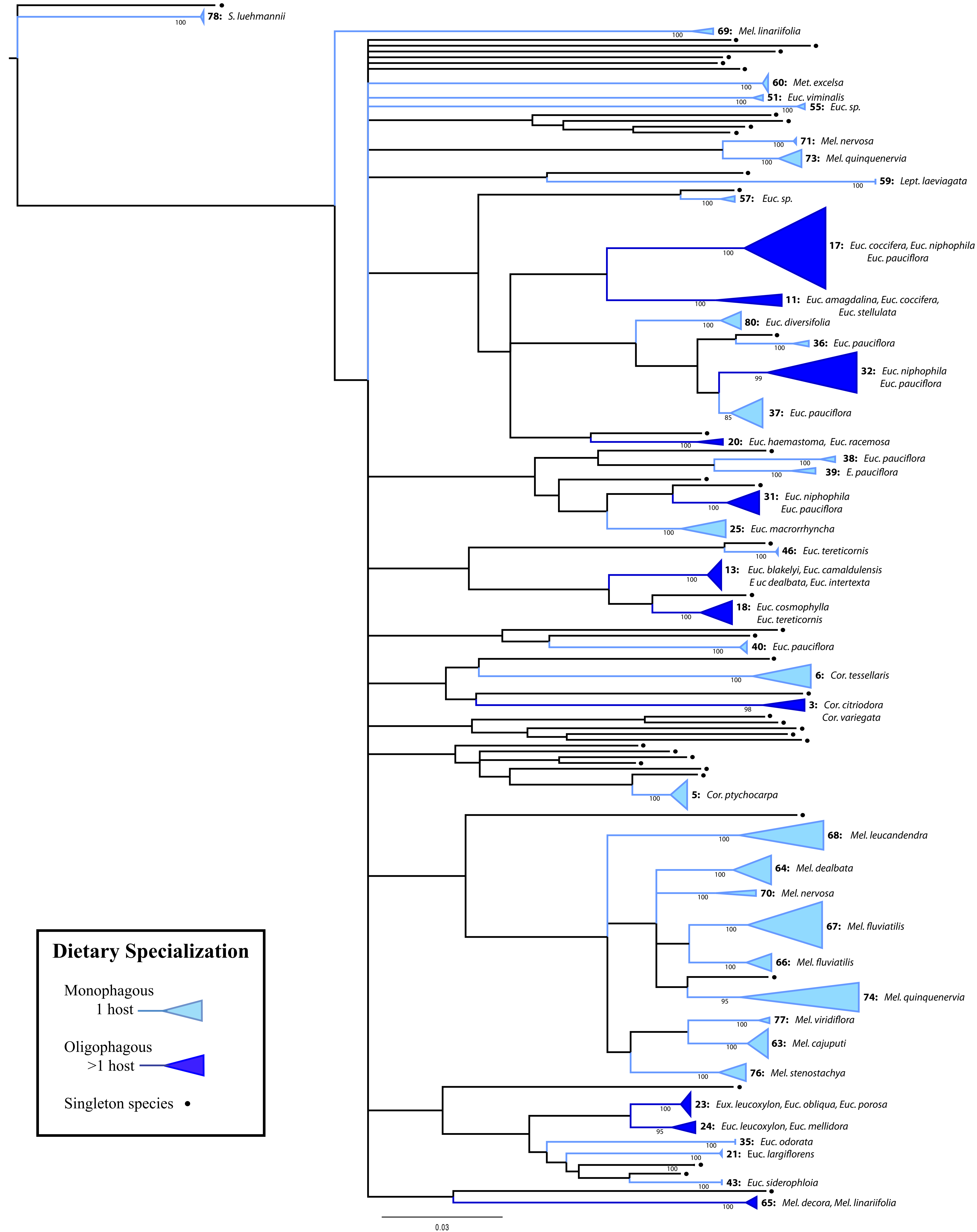


Figure 3. Relationships between average intraspecific pairwise distance and a) sample size of each species; and b) maximum geographic distance of samples within each species. Bonferroni correction for multiple tests requires significance criterion of $\mathrm{p}<0.05$ to be reduced to $\mathrm{p}<0.008$.

a) Average pairwise distance and sample size. All data: $\mathrm{r}=0.20, \mathrm{n}=40, \mathrm{p}>0.20, \mathrm{NS}$

Monophogous only: $r=0.35, n=29, p=0.064$, NS

Oligophagous only: $r=-0.23, n=11, p>0.40$, NS

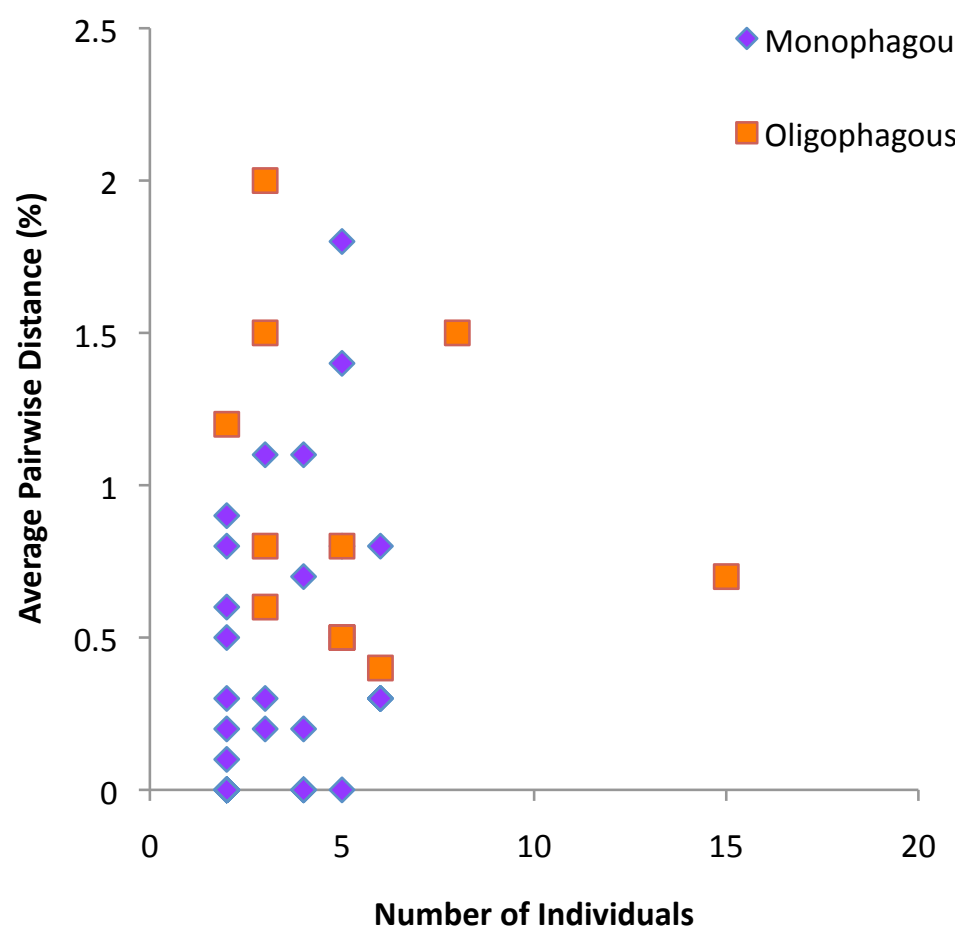

b) Average pairwise distance and geographic distance.

All data: $\mathrm{r}=0.12, \mathrm{n}=40, \mathrm{p}>0.20$, NS

Monophogous only: $r=0.23, \mathrm{n}=29, \mathrm{p}>0.20$, NS

Oligophagous only: $r=-0.27, \mathrm{n}=11, \mathrm{p}>0.40$, NS

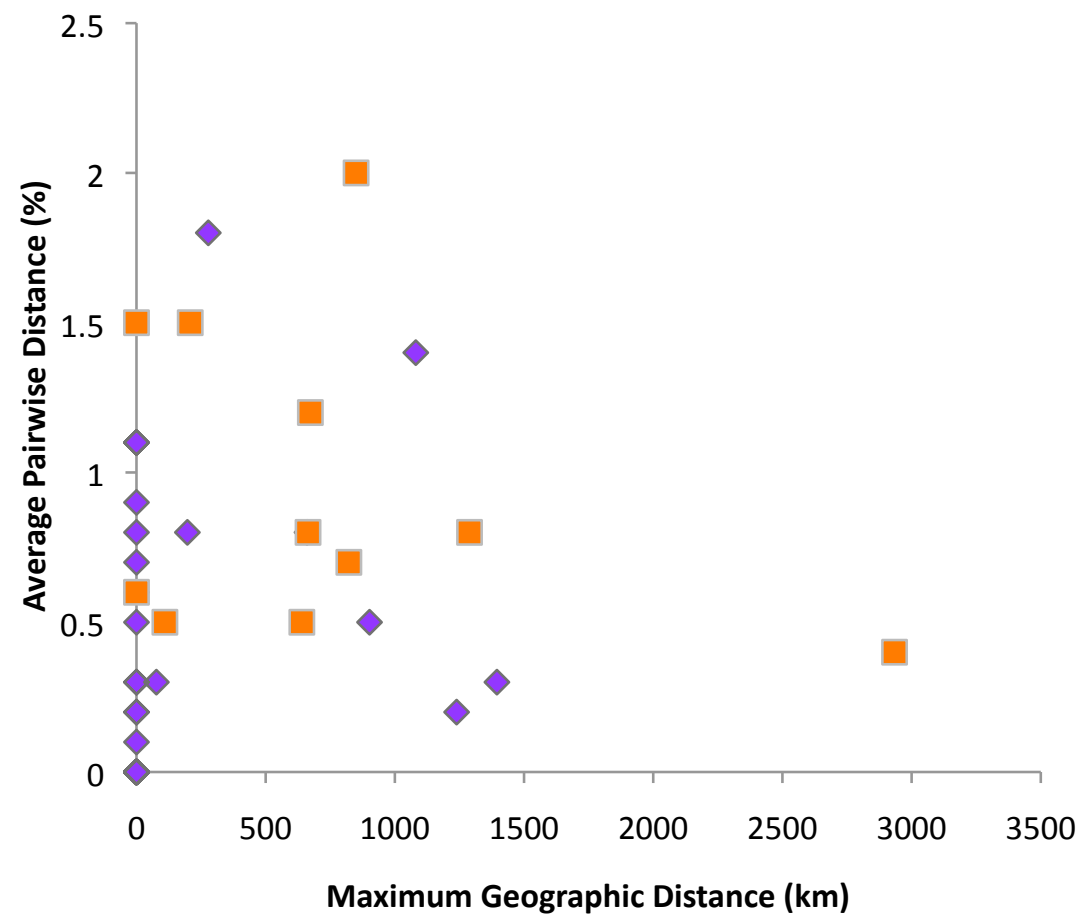




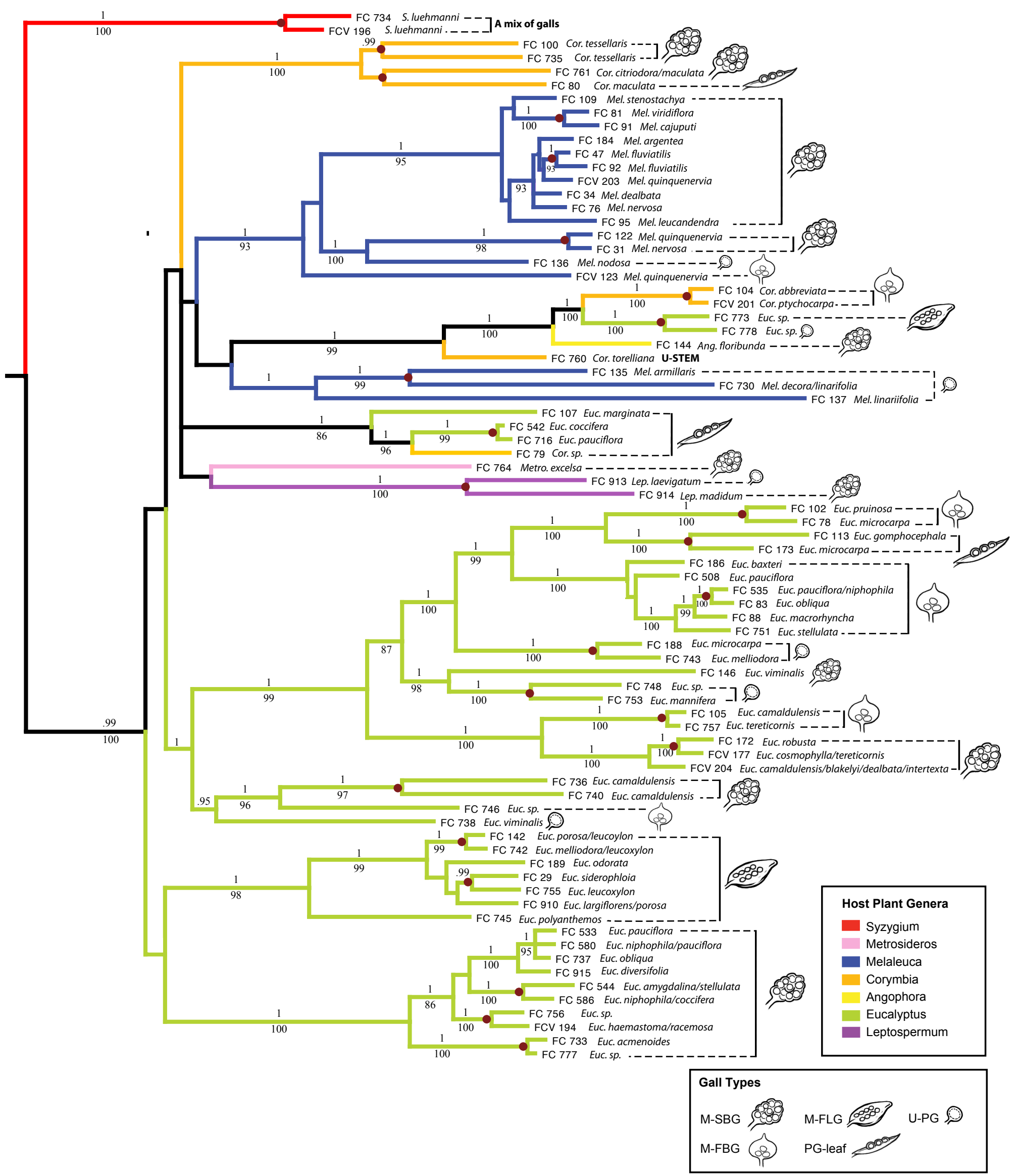




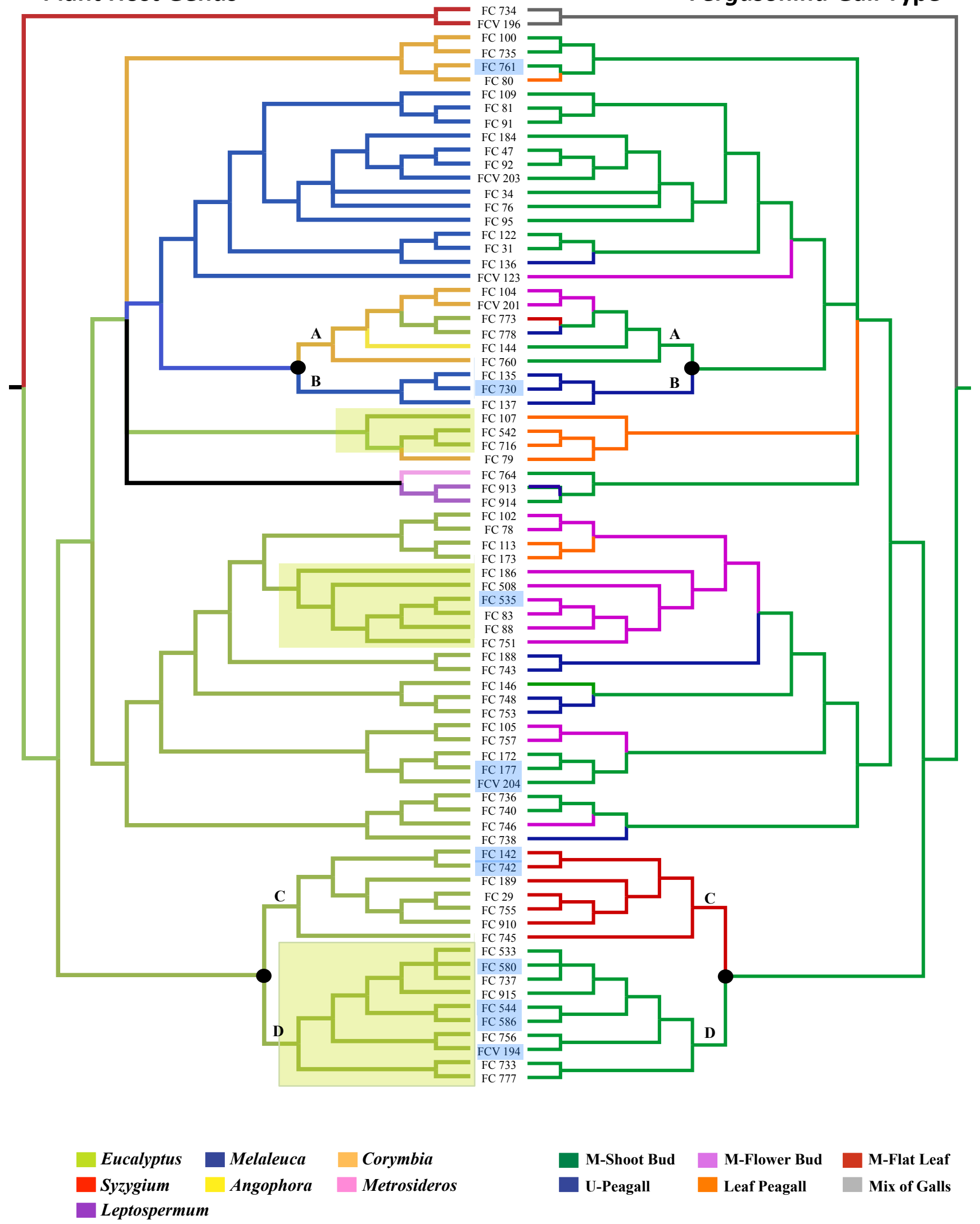


Table 1. Collection information for each specimen. When present in the figures, text, other tables, and GenBank, the code number will be preceded by "FC-“ or "FCV-“. Host genus abbreviations are as follows: A=Angophora, C=Corymbia, E=Eucalyptus, M=Melaleuca, Metr=Metrosideros, L=Leptospermum, S=Syzyium. Further information on Gall type can be found in Table 2. All specimens were collected from Australia with the exception of samples from Metrosideros excelsa in New Zealand. Australian state abbreviations used here are: ACT, Australian National Territory; NSW, New South Wales; QLD, Queensland; SA, South Australia; TAS, Tasmania; VIC, Victoria; WA, Western Australia.

\begin{tabular}{|c|c|c|c|c|}
\hline Code \# & Host Plant & Gall Type & Date & Collection Location \\
\hline 18 & E. diversifolia & M-Shoot Bud & $04 / 1999$ & SA, Meninge \\
\hline 19 & E. leucoxylon & M-Flat Leaf & 04/1999 & SA, Meninge \\
\hline 20 & M. quinquenervia & M-Shoot Bud & 07/1999 & QLD, N. Stradbroke Island \\
\hline 21 & M. fluviatilis & M-Shoot Bud & 08/1999 & QLD, Home Hill \\
\hline 22 & M. leucandendra & M-Shoot Bud & 08/1999 & QLD, Cairns \\
\hline 23 & M. dealbata & M-Shoot Bud & 08/1999 & QLD, Cairns \\
\hline 24 & M. cajuputi & M-Shoot Bud & 08/1999 & QLD, Daintree Lagoon \\
\hline 25 & M. cajuputi & M-Shoot Bud & 08/1999 & QLD, Daintree Lagoon \\
\hline 26 & C. ptychocarpa & M-Flower Bud & 08/1999 & QLD, Daintree Lagoon \\
\hline 27 & C. ptychocarpa & M-Flower Bud & 08/1999 & QLD, Sherwood \\
\hline 29 & E. siderophloia & M-Flat Leaf & 07/1999 & QLD, Taringa, Brisbane \\
\hline 30 & M. dealbata & M-Shoot Bud & 08/1999 & QLD, Cairns \\
\hline 31 & M. nervosa & U-Peagall & 08/1999 & QLD, Mareeba \\
\hline 33 & M. leucandendra & M-Shoot Bud & 08/1999 & QLD, Cairns \\
\hline 34 & M. dealbata & M-Shoot Bud & 08/1999 & QLD, Cairns \\
\hline 35 & M. cajuputi & M-Shoot Bud & 08/1999 & QLD, Daintree Lagoon \\
\hline 36 & C. ptychocarpa & M-Flower Bud & 08/1999 & QLD, Sherwood \\
\hline 37 & E. racemosa & M-Shoot Bud & 07/1999 & QLD, N. Stradbroke Island \\
\hline 38 & M. quinquenervia & M-Shoot Bud & 08/1999 & NSW, Woodburn \\
\hline 39 & E. siderophloia & M-Flat Leaf & 07/1999 & QLD, Brisbane \\
\hline 40 & M. dealbata & M-Shoot Bud & 06/1999 & QLD, Cardwell \\
\hline 41 & M. nervosa & U-Peagall & 08/1999 & QLD, Mareeba \\
\hline 42 & M. cajuputi & M-Shoot Bud & 08/1999 & QLD, Daintree Ferry Turn \\
\hline 43 & M. fluviatilis & M-Shoot Bud & 06/1999 & QLD, Home Hill \\
\hline 45 & M. quinquenervia & M-Shoot Bud & 06/1999 & QLD, N. Stradbroke Island \\
\hline 46 & M. dealbata & M-Shoot Bud & 05/1999 & QLD, Cardwell \\
\hline 47 & M. fluviatilis & M-Shoot Bud & 06/1999 & QLD, Townsville, Ross River Dam \\
\hline 48 & C. ptychocarpa & M-Flower Bud & 1999 & QLD, Indooroopilly \\
\hline
\end{tabular}




$\begin{array}{lll}\mathbf{5 2} & \text { M. leucandendra } & \text { M-Shoot Bud } \\ \mathbf{5 3} & \text { M. } \text { cajuputi } & \text { M-Shoot Bud } \\ \mathbf{5 5} & \text { M. fluviatilis } & \text { M-Shoot Bud } \\ \mathbf{6 1} & \text { E. camaldulensis } & \text { M-Shoot Bud } \\ \mathbf{6 4} & \text { E. macrorhyncha } & \text { M-Flower } \\ \mathbf{6 7} & \text { M. } \text { stenostachya } & \text { M-Shoot Bud } \\ \mathbf{6 8} & \text { M. } \text { viridiflora } & \text { M-Shoot Bud } \\ \mathbf{7 0} & \text { E. diversifolia } & \text { M-Shoot Bud } \\ \mathbf{7 1} & \text { E. macrorhyncha } & \text { M-Flower Bud } \\ \mathbf{7 3} & \text { E. intertexta } & \text { M-Shoot Bud } \\ \mathbf{7 4} & \text { E. leucoxylon } & \text { M-Flat Leaf } \\ \mathbf{7 5} & \text { M. fluviatilis } & \text { M-Shoot Bud } \\ \mathbf{7 6} & \text { M. nervosa } & \text { M-Shoot Bud } \\ \mathbf{7 7} & \text { M. stenostachya } & \text { M-Shoot Bud } \\ \mathbf{7 8} & \text { E. microcarpa } & \text { M-Flower Bud } \\ \mathbf{7 9} & \text { Corymbia } & \text { Leaf Peagall } \\ \mathbf{8 0} & \text { C. maculata } & \text { Leaf Peagall } \\ \mathbf{8 1} & \text { M. } \text { viridiflora } & \text { M-Shoot Bud } \\ \mathbf{8 3} & \text { E. obliqua } & \text { M-Flower Bud } \\ \mathbf{8 4} & \text { M. } \text { nervosa } & \text { M-Shoot Bud } \\ \mathbf{8 5} & \text { E. leucoxylon } & \text { M-Flat Leaf } \\ \mathbf{8 8} & \text { E. macrorhyncha } & \text { M-Flower Bud } \\ \mathbf{8 9} & \text { E. siderophloia } & \text { M-Flat Leaf } \\ \mathbf{9 1} & \text { M. cajuputi } & \text { M-Shoot Bud } \\ \mathbf{9 2} & \text { M. fluviatilis } & \text { M-Shoot Bud } \\ \mathbf{9 3} & \text { M. fluviatilis } & \text { M-Shoot Bud } \\ \mathbf{9 4} & \text { M. leucadendra } & \text { M-Shoot Bud } \\ \mathbf{9 5} & \text { M. leucadendra } & \text { M-Shoot Bud } \\ \mathbf{9 8} & \text { Eucalyptus sp. } & \text { M-Flat Leaf } \\ \mathbf{9 9} & \text { E. siderophloia? } & \text { Leaf Peagall } \\ \mathbf{1 0 0} & \text { C. tessellaris? } & \text { M-Shoot Bud } \\ \mathbf{1 0 1} & \text { M. } \text { quinquenervia } & \text { M-Shoot Bud } \\ \mathbf{1 0 2} & \text { E. pruinosa } & \text { M-Flower Bud } \\ & & \\ \mathbf{1 0 4} & \text { C. abbreviata } & \text { M-Flower Bud } \\ \mathbf{1 0 5} & \text { E. camaldulensis } & \text { M-Flower Bud } \\ \mathbf{1 0 7} & \text { E. marginata } & \text { Leaf Peagall } \\ & & \end{array}$

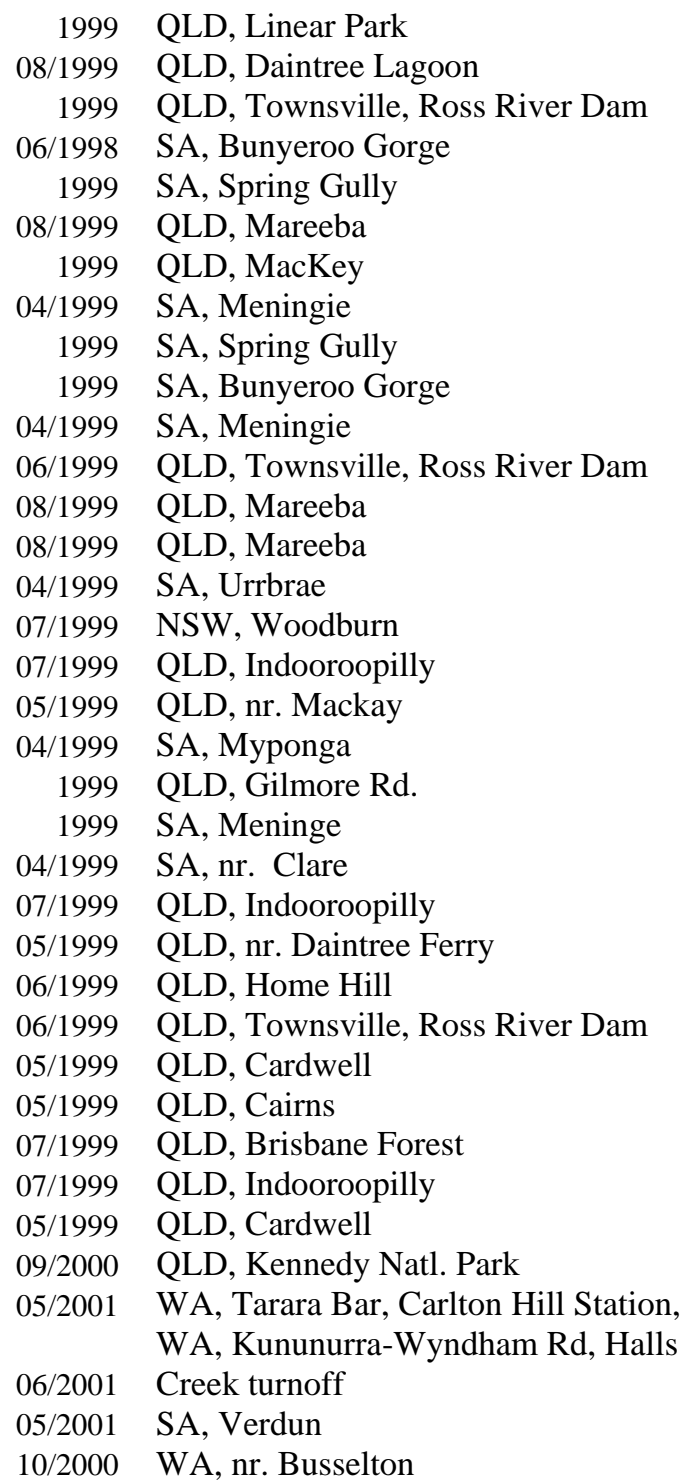




$\begin{array}{lll}\mathbf{1 0 8} & \text { M. stenostachya } & \text { M-Shoot Bud } \\ \mathbf{1 0 9} & \text { M. } \text { stenostachya } & \text { M-Shoot Bud } \\ \mathbf{1 1 0} & \text { M. } \text { fluviatilis } & \text { M-Shoot Bud } \\ \mathbf{1 1 3} & \text { E. gomphocephala } & \text { Leaf Peagall } \\ \mathbf{1 1 4} & \text { E. cosmophylla } & \text { M-Shoot Bud } \\ \mathbf{1 1 8} & \text { E. } \text { camaldulensis } & \text { M-Shoot Bud } \\ \mathbf{1 2 0} & \text { E. leucoxylon } & \text { M-Flat Leaf } \\ \mathbf{1 2 1} & \text { E. viminalis } & \text { M-Shoot Bud } \\ \mathbf{1 2 2} & \text { M. quinquenervia } & \text { M-Shoot Bud } \\ \mathbf{1 2 3} & \text { M. quinquenervia } & \text { M-Flower Bud } \\ \mathbf{1 2 4} & \text { M. } \text { fluviatilis } & \text { M-Shoot Bud } \\ \mathbf{1 2 7} & \text { M. quinquenervia } & \text { M-Shoot Bud } \\ & & \text { M-Shoot Bud } \\ \mathbf{1 3 1} & \text { Met. excelsa } & \\ & & \text { M-Shoot Bud } \\ \mathbf{1 3 2} & \text { Met. excelsa } & \\ \mathbf{1 3 4} & \text { E. tereticornis } & \text { M-Shoot Bud } \\ \mathbf{1 3 5} & \text { M. armillaris } & \text { U-Peagall } \\ \mathbf{1 3 6} & \text { M. nodosa } & \text { U-Peagall } \\ \mathbf{1 3 7} & \text { M. linariifolia } & \text { U-Peagall } \\ \mathbf{1 3 9} & \text { S. luehmannii } & \text { Mix of galls } \\ \mathbf{1 4 0} & \text { M. decora } & \text { U-Peagall } \\ \mathbf{1 4 2} & \text { E. porosa } & \text { M-Flat Leaf } \\ \mathbf{1 4 3} & \text { E. blakelyi } & \text { M-Shoot Bud } \\ \mathbf{1 4 4} & \text { A. floribunda } & \text { M-Shoot Bud } \\ \mathbf{1 4 5} & \text { Eucalyptus sp. } & \text { M-Flat Leaf } \\ \mathbf{1 4 6} & \text { E. viminalis? } & \text { M-Shoot Bud } \\ \mathbf{1 4 7} & \text { E. pauciflora } & \text { Leaf Peagall } \\ \mathbf{1 4 8} & \text { E. amygdalina } & \text { M-Shoot Bud } \\ \mathbf{1 5 2} & \text { M. quinquenervia } & \text { M-Shoot Bud } \\ \mathbf{1 6 9} & \text { E. tereticornis } & \text { M-Shoot Bud } \\ \mathbf{1 7 0} & \text { M. linariifolia } & \text { U-Peagall } \\ \mathbf{1 7 1} & \text { C. tessellaris } & \text { M-Shoot Bud } \\ \mathbf{1 7 2} & \text { E. robusta } & \text { M-Shoot Bud } \\ \mathbf{1 7 3} & \text { E. microcarpa } & \text { Leaf Peagall } \\ \mathbf{1 7 7} & \text { E. cosmophylla } & \text { M-Shoot Bud } \\ \mathbf{1 8 0} & \text { C. ptychocarpa } & \text { M-Flower Bud } \\ & & \end{array}$

12/2000 QLD, Luster Creek, nr. Cairns

12/2000 QLD, Luster Creek, nr. Cairns

09/2000 QLD, Townsville

10/2000 WA, Cervantes Caravan Park

12/2000 SA, Kangaroo Island

10/2000 WA, Kellerberin

11/1999 SA, Hazelwood Park

09/1999 SA, Cleland Conservation Park

06/2001 QLD, Edmund Kennedy Natl. Park

06/2001 QLD, Edmund Kennedy Natl. Park

06/2001 QLD, Home Hill

09/2000 QLD, Edmund Kennedy Natl. Park

Karekare Beach, North Island, New

03/2004 Zealand

Karekare Beach, North Island, New

03/2004 Zealand

07/2004 NSW, Sydney

07/2004 NSW, Hawk's Nest

07/2004 NSW, Hawk's Nest

07/2004 NSW, Port Macquarie

07/2004 QLD, Tolga

07/2004 QLD, Ingham

09/2003 SA, nr. Wool Bay

01/2004 ACT, Canberra

01/2004 NSW, nr. Mudgee

01/2004 ACT, Cotter Rd.

01/2004 NSW, nr. Mt. Crackenback

11/2002 TAS, nr. Bridport

11/2002 TAS, nr. Mt Cameron

07/2004 NSW, Arrawarra

07/2004 NSW, Sydney

07/2004 NSW, Port Macquarie

07/2004 QLD, Cardwell

04/2002 NSW, Cogarah Bay

08/2001 SA, Urrbrae, Waite Arboretum

12/2000 SA, Kangaroo Island

07/2004 QLD, Cairns 


\begin{tabular}{lll}
$\mathbf{1 8 3}$ & M. quinquenervia & M-Shoot Bud \\
$\mathbf{1 8 4}$ & M. argentea & M-Shoot Bud \\
$\mathbf{1 8 6}$ & E. baxteri & M-Flower Bud \\
$\mathbf{1 8 8}$ & E. microcarpa? & U-Peagall \\
$\mathbf{1 8 9}$ & E. odorata? & M-Flat Leaf \\
$\mathbf{1 9 0}$ & E. odorata? & M-Flat Leaf \\
$\mathbf{1 9 4}$ & E. haemastoma & M-Shoot Bud \\
$\mathbf{1 9 6}$ & S. luehmannii & Mix of galls \\
& & M-Shoot Bud \\
$\mathbf{1 9 8}$ & M. excelsa & \\
$\mathbf{1 9 9}$ & E. tereticornis & M-Shoot Bud \\
$\mathbf{2 0 0}$ & S. luehmannii & Mix of galls \\
$\mathbf{2 0 1}$ & C. ptychocarpa & M-Flower Bud \\
$\mathbf{2 0 3}$ & M. quinquenervia & M-Shoot Bud \\
$\mathbf{2 0 4}$ & E. camaldulensis & M-Shoot Bud \\
$\mathbf{5 0 0}$ & E. pauciflora & M-Shoot Bud \\
$\mathbf{5 0 3}$ & E. pauciflora & M-Shoot Bud \\
$\mathbf{5 0 6}$ & E. pauciflora & M-Shoot Bud \\
$\mathbf{5 0 8}$ & E. pauciflora & M-Flower Bud \\
$\mathbf{5 0 9}$ & E. pauciflora & M-Shoot Bud \\
$\mathbf{5 1 0}$ & E. pauciflora & M-Shoot Bud \\
$\mathbf{5 1 1}$ & E. pauciflora & Leaf Peagall \\
$\mathbf{5 1 2}$ & E. pauciflora & M-Shoot Bud \\
$\mathbf{5 1 5}$ & E. niphophila & M-Shoot Bud \\
$\mathbf{5 2 1}$ & E. niphophila & M-Shoot Bud \\
$\mathbf{5 2 2}$ & E. niphophila & M-Shoot Bud \\
$\mathbf{5 2 3}$ & E. niphophila & M-Shoot Bud \\
$\mathbf{5 2 6}$ & E. niphophila & M-Shoot Bud \\
$\mathbf{5 2 9}$ & E. pauciflora & M-Shoot Bud \\
$\mathbf{5 3 5}$ & E. pauciflora & M-Flower Bud \\
$\mathbf{5 3 9}$ & E. pauciflora & M-Shoot Bud \\
$\mathbf{5 4 0}$ & E. pauciflora & M-Flower Bud \\
$\mathbf{5 4 1}$ & E. coccifera & M-Shoot Bud \\
$\mathbf{5 4 2}$ & E. coccifera & Leaf Peagall \\
$\mathbf{5 4 3}$ & E. coccifera & M-Shoot Bud \\
$\mathbf{5 4 4}$ & E. stellulata & M-Shoot Bud \\
$\mathbf{5 8 0}$ & E. niphophila & M-Shoot Bud \\
& & \\
\hline
\end{tabular}

$\begin{array}{ll}07 / 2004 & \text { QLD, Edmund Kennedy Natl. Park } \\ 08 / 2004 & \text { NT, 30km ESE Darwin, Elizabeth River } \\ 11 / 2000 & \text { VIC, Grampians } \\ 09 / 1999 & \text { SA, Robertstown } \\ 09 / 1999 & \text { SA, nr. Nuriootpa } \\ 09 / 1999 & \text { SA, nr. Nuriootpa } \\ 01 / 2007 & \text { NSW, Kuringai } \\ 07 / 2004 & \text { QLD, Tolga } \\ & \text { Karekare Beach, North Island, New } \\ 03 / 2004 & \text { Zealand } \\ 07 / 2004 & \text { NSW, Sydney } \\ 07 / 2004 & \text { QLD, Tolga } \\ 07 / 2004 & \text { QLD, Cairns } \\ 07 / 2004 & \text { NSW, Kingscliff } \\ 01 / 2002 & \text { SA, Erindale } \\ 09 / 2007 & \text { NSW, Braidwood } \\ 09 / 2007 & \text { NSW, Captain's Flat Rd } \\ 09 / 2007 & \text { ACT, Edmondson Rest Area } \\ 10 / 2007 & \text { ACT, Edmondson Rest Area } \\ 09 / 2007 & \text { NSW, Pt Lookout } \\ 09 / 2007 & \text { NSW, Pt Lookout } \\ 09 / 2007 & \text { NSW, Pt Lookout } \\ 09 / 2007 & \text { NSW, Namadgi Natl. Park } \\ 11 / 2007 & \text { ACT, Mt. Gingera } \\ 09 / 2007 & \text { VIC, Mt. Buffalo } \\ 09 / 2007 & \text { VIC, Mt. Buffalo } \\ 09 / 2007 & \text { VIC, Mt. Buffalo } \\ 09 / 2007 & \text { VIC, Mt. Hotham } \\ 09 / 2007 & \text { VIC, Dinner Plains } \\ 10 / 2007 & \text { TAS, Rd C526 (in eastern TAS) } \\ 10 / 2007 & \text { TAS, Great Lake } \\ 10 / 2007 & \text { TAS, Rd C526 (in eastern TAS) } \\ 10 / 2007 & \text { TAS, Mt. Wellington } \\ 10 / 2007 & \text { TAS, Mt. Wellington } \\ 10 / 2007 & \text { TAS, Mt. Field } \\ 11 / 2007 & \text { ACT, Mt. Gingera } \\ 09 / 2007 & \text { VIC, Falls Creek Village } \\ & \end{array}$




\begin{tabular}{|c|c|c|}
\hline 586 & E. niphophila & M-Shoot Bud \\
\hline 602 & E. coccifera & M-Shoot Bud \\
\hline 603 & E. coccifera & M-Shoot Bud \\
\hline 606 & E. coccifera & M-Shoot Bud \\
\hline 608 & E. coccifera & M-Shoot Bud \\
\hline 609 & E. pauciflora & M-Shoot Bud \\
\hline 610 & E. pauciflora & M-Shoot Bud \\
\hline 618 & E. pauciflora & M-Shoot Bud \\
\hline 619 & E. pauciflora & M-Shoot Bud \\
\hline 632 & E. pauciflora & M-Shoot Bud \\
\hline 633 & E. pauciflora & M-Shoot Bud \\
\hline 649 & E. pauciflora & M-Shoot Bud \\
\hline 652 & E. pauciflora & M-Shoot Bud \\
\hline 659 & E. pauciflora & M-Shoot Bud \\
\hline 710 & E. pauciflora & M-Shoot Bud \\
\hline 711 & E. pauciflora & M-Shoot Bud \\
\hline 716 & E. pauciflora & Leaf Peagall \\
\hline 718 & E. pauciflora & M-Flower Buc \\
\hline 719 & Eucalyptus sp. & M-Flower Buc \\
\hline 720 & E. pauciflora & M-Flower Buc \\
\hline 721 & E. pauciflora & M-Flower Buc \\
\hline 724 & E. niphophila & M-Flower B \\
\hline 725 & E. niphophila & M-Flower Buc \\
\hline 730 & M. decora & U-Peagall \\
\hline 731 & C. tesselaris & M-Shoot Bud \\
\hline 732 & M. dealbata & M-Shoot Bud \\
\hline 733 & E. acmenoides & M-Shoot Bud \\
\hline 734 & S. luehmannii & Mix of Galls \\
\hline 735 & C. tesselaris & M-Shoot Bud \\
\hline 736 & E. camaldulensis & M-Shoot Bud \\
\hline 737 & E. obliqua & M-Shoot Bud \\
\hline 738 & E. viminalis & U-Peagall \\
\hline 739 & E. viminalis & U-Peagall \\
\hline 740 & E. camaldulensis & M-Shoot Bud \\
\hline 741 & E. siderophloia & M-Flat Leaf \\
\hline 742 & E. melliodora & M-Flat Leaf \\
\hline
\end{tabular}

$\begin{array}{ll}\text { 09/2007 } & \text { VIC, Mt. Hotham Village } \\ \text { 10/2007 } & \text { TAS, Mt. Wellington } \\ \text { 10/2007 } & \text { TAS, Mt. Wellington } \\ \text { 10/2007 } & \text { TAS, Mt. Field } \\ \text { 10/2007 } & \text { TAS, Mt. Field } \\ \text { 10/2007 } & \text { TAS, Great Lake } \\ \text { 10/2007 } & \text { TAS, Great Lake } \\ 11 / 2007 & \text { ACT, Mt. Gingera } \\ \text { 11/2007 } & \text { ACT, Mt. Gingera } \\ 11 / 2007 & \text { ACT, Mt. Gingera } \\ 11 / 2007 & \text { ACT, Mt. Gingera } \\ 06 / 2007 & \text { NSW, Perisher Ski Area, Eyre T-Bar } \\ 09 / 2007 & \text { NSW, Mt Koziosco, Dead Horse Gap } \\ 09 / 2007 & \text { VIC, Falls Creek Village } \\ 10 / 2007 & \text { TAS, nr. Avoca } \\ 10 / 2007 & \text { TAS, nr. Avoca } \\ 10 / 2007 & \text { TAS, east of Bridport } \\ 09 / 2007 & \text { NSW, Kings Highway, nr. Bungendore } \\ 09 / 2007 & \text { NSW, Goulburn } \\ 09 / 2007 & \text { NSW, Edmonston Rest Area } \\ 09 / 2007 & \text { NSW, Edmonston Rest Area } \\ 09 / 2007 & \text { VIC, Mt. Buffalo } \\ 09 / 2007 & \text { VIC, Mt. Buffalo } \\ 08 / 2007 & \text { QLD, Ingham } \\ 08 / 2007 & \text { QLD, Mission Beach } \\ 08 / 2007 & \text { QLD, Ingham } \\ 08 / 2007 & \text { QLD, nr. Cardwell } \\ 08 / 2007 & \text { QLD, Tolga } \\ & \text { QLD, Edmund Kennedy Natl. Park, } \\ 08 / 2007 & \text { Cardwell } \\ 09 / 2007 & \text { SA, Stonyfell } \\ 09 / 2007 & \text { SA, Stirling } \\ 09 / 2007 & \text { SA, Arbury Park, Stirling } \\ 09 / 2007 & \text { SA, Arbury Park, Stirling } \\ 09 / 2007 & \text { SA, Stonyfell, Adelaide } \\ 02 / 2008 & \text { ACT, Black Mt. Peninsula } \\ 12 / 2007 & \text { ACT, Canberra, Black Mt. Peninsula }\end{array}$




\begin{tabular}{|c|c|c|c|c|}
\hline 743 & E. melliodora & U-Peagall & $12 / 2007$ & ACT, Canberra, Black Mt. Peninsula \\
\hline 745 & E. polyanthemos? & M-Flat Leaf & $12 / 2007$ & ACT, Canberra, Pearce \\
\hline 746 & Eucalyptus sp. & M-Flower Bud & 09/2007 & NSW, nr. Goulburn \\
\hline 748 & Eucalyptus sp. & U-Peagall & 09/2007 & NSW, Ben Lomond \\
\hline 749 & Eucalyptus sp. & U-Peagall & 09/2007 & NSW, Namigi National Park \\
\hline 750 & E. niphophila & M-Flower Bud & 09/2007 & NSW, Bullocks Flat \\
\hline 751 & E. stellulata & M-Flower Bud & $10 / 2007$ & ACT, Canberra, Jerrabomberra \\
\hline 753 & E. mannifera & U-Peagall & $12 / 2007$ & ACT, Canberra, ANU \\
\hline 754 & E. leucoxylon & M-Flat Leaf & $12 / 2007$ & $\mathrm{ACT}$, Canberra \\
\hline 755 & E. leucoxylon & M-Flat Leaf & $12 / 2007$ & ACT, Canberra, ANU \\
\hline 756 & Eucalyptus sp. & M-Shoot Bud & 07/2007 & ACT, Canberra, Black Mountain \\
\hline 757 & E. tereticornis & M-Flower Bud & $07 / 2008$ & QLD, Sarina \\
\hline 758 & E. tereticornis & M-Flower Bud & 07/2008 & QLD, Sarina \\
\hline 759 & M. linariifolia & U-Peagall & 07/2008 & QLD, Mackay \\
\hline 760 & C. torelliana & M-Shoot Bud & $07 / 2008$ & QLD, Kairi \\
\hline 761 & C. citriodora & M-Shoot Bud & $05 / 2008$ & NSW, Woondum \\
\hline 762 & C. maculata & M-Shoot Bud & $07 / 2008$ & NSW, Forster \\
\hline 763 & C. citriodora & M-Shoot Bud & $07 / 2008$ & QLD, Woondum \\
\hline 764 & Metr. excelsa & M-Shoot Bud & $11 / 2004$ & New Zealand, Karekare Beach \\
\hline 771 & C. tesselaris & M-Shoot Bud & $05 / 2002$ & QLD, Hervey Bay \\
\hline 773 & Eucalyptus sp. & M-Flat Leaf & $05 / 2002$ & QLD, Lake Tinnaroo \\
\hline 774 & C. tesselaris & M-Shoot Bud & $05 / 2002$ & QLD, Ingham \\
\hline 775 & E. dealbata & M-Shoot Bud & $11 / 2007$ & NSW, Breeza \\
\hline 777 & Eucalyptus sp. & M-Shoot Bud & 07/1999 & NSW, Woodburn \\
\hline 778 & Eucalyptus sp. & U-Peagall & 07/1999 & NSW, Woodburn \\
\hline 779 & Eucalyptus sp. & M-Flat Leaf & 07/1999 & NSW, Woodburn \\
\hline 780 & E. tereticornis & Leaf Peagall & 1999 & QLD, Indooroopilly \\
\hline 910 & E. largiflorens & M-Flat Leaf & 07/2011 & NSW, Kincheaga National Park \\
\hline 911 & E. largiflorens & M-Flat Leaf & 07/2011 & NSW, Kincheaga National Park \\
\hline 912 & L. laevigatum & U-PG & $07 / 2012$ & VIC, nr. Frankston \\
\hline 913 & L. laevigatum & U-PG & $07 / 2012$ & VIC, nr. Frankston \\
\hline 914 & L. madidum & M-Shoot Bud & $07 / 2012$ & QLD, nr. Injiinoo \\
\hline 915 & E. diversifolia & M-Shoot Bud & $02 / 2011$ & SA, nr. Meningie \\
\hline 916 & E. diversifolia & M-Shoot Bud & $02 / 2011$ & SA, nr. Meningie \\
\hline
\end{tabular}


Table 2. Gall classification scheme used in this study (modified from Nelson et al. 2014). Multilocular galls indicated by "M"; unilocular galls indicated by "U."

\begin{tabular}{|c|c|c|c|c|}
\hline Gall & Gall Type & Locules & Plant Tissue & Notes \\
\hline & $\begin{array}{l}\text { M-Shoot } \\
\text { Bud }\end{array}$ & $\mathrm{M}$ & shoot bud & $\begin{array}{l}\text { Spherical, teardrop, or cigar- } \\
\text { shaped, involving apical, } \\
\text { axillary, or leaf buds }\end{array}$ \\
\hline & M-Flat Leaf & $\mathrm{M}$ & leaf blade & $\begin{array}{l}\text { Hypertrophied or puffy leaf } \\
\text { blades, with locules arranged } \\
\text { internally in tight rows }\end{array}$ \\
\hline & $\begin{array}{l}\text { M-Flower } \\
\text { Bud }\end{array}$ & $\mathrm{M}$ & flower bud & $\begin{array}{l}\text { Hypertrophied flower buds, } \\
\text { locules located in various } \\
\text { tissues, including stamens, } \\
\text { anthers, top of stigmata, base of } \\
\text { stigmata }\end{array}$ \\
\hline & U-Peagall & $\mathrm{U}$ & axillary bud & $\begin{array}{l}\text { Pea-shaped in leaf axil, sessile or } \\
\text { stalked }\end{array}$ \\
\hline & Leaf Peagall & U-M & leaf blade & $\begin{array}{l}\text { Pea-shaped on leaf surface, one } \\
\text { to several in a row }\end{array}$ \\
\hline
\end{tabular}


Table 3. Primers used for PCR amplification (P) and DNA sequencing (S). Most commonly used primers indicated with an asterix. Remaining primers used to obtain additional sequencing reads as needed.

\begin{tabular}{|c|c|c|c|c|}
\hline Primer & Direction & Use & Sequence & Reference \\
\hline \multicolumn{5}{|l|}{ COI } \\
\hline TY-J-1461* & $\mathrm{F}$ & $\mathrm{P}, \mathrm{S}$ & TTTACARTTTACCGCCTATTRTCAGCCA & Winkler et al. 2009 \\
\hline LCO1490 & $\mathrm{F}$ & $\mathrm{P}, \mathrm{S}$ & GGTCAACAAATCATAAAGATATTGG & Folmer et al. 1994 \\
\hline C1-N-1958 & $\mathrm{R}$ & S & CGTATATTAATAATTGTTGTAATAA & Scheffer and Wiegmann 2000 \\
\hline C1-N-2004 & $\mathrm{R}$ & $\mathrm{S}$ & CAAATARNGGTATTCGA & this project \\
\hline C1-J-2183* & $\mathrm{F}$ & $\mathrm{S}$ & CAACATTTATTTTGATTTTTTGG & Simon et al. 1994 \\
\hline C1-N-2191 & $\mathrm{R}$ & $\mathrm{S}$ & CCCGGTAAAATTAAAATATAAACTTC & Simon et al. 1994 \\
\hline $\mathrm{HCO} 2198$ & $\mathrm{R}$ & $\mathrm{S}$ & TAAACTTCAGGGTGACCAAAAAATCA & Folmer et al. 1994 \\
\hline C1-J-2441 mod & $\mathrm{F}$ & S & CCTACAGGAATTAAAATTTTTAGTTGATTAGC & Scheffer et al. 2004 \\
\hline $\mathrm{C} 1-\mathrm{N}-2413^{*}$ & $\mathrm{R}$ & $\mathrm{S}$ & TCARCTRAAAATTTTAATTCCTGT & Winkler et al. 2009 \\
\hline C1-N-2508 & $\mathrm{R}$ & $\mathrm{S}$ & CTCCAGTTAATCCTCCAACTGTAAAT & Scheffer et al. 2004 \\
\hline TL2-N-3014 * & $\mathrm{R}$ & $\mathrm{P}, \mathrm{S}$ & TCCATTGCACTAATCTGCCATATTA & Simon et al. 1994 \\
\hline \multicolumn{5}{|l|}{ CAD } \\
\hline $54 \mathrm{~F} *$ & $\mathrm{~F}$ & $\mathrm{P}, \mathrm{S}$ & GTNGTNTTYCARACNGGNATGGT & Moulton and Wiegmann 2004 \\
\hline AG-360AR & $\mathrm{R}$ & $\mathrm{S}$ & CCATGATTYTGTGARGTCAT & Scheffer et al. 2007 \\
\hline AG-360BR & $\mathrm{R}$ & S & CCRTGRTTYTGTGAYGTCAT & Scheffer et al. 2007 \\
\hline $405 \mathrm{R} *$ & $\mathrm{R}$ & $\mathrm{P}$ & GCNGTRTGYTCNGGRTGRAAYTG & Moulton and Wiegmann 2004 \\
\hline \multicolumn{5}{|l|}{ PGD } \\
\hline $2 \mathrm{~F} *$ & $\mathrm{~F}$ & $\mathrm{P}, \mathrm{S}$ & ATHGARTAYGGNGAYATGCA & Regier 2008 \\
\hline $2.5 \mathrm{R} *$ & $\mathrm{R}$ & $\mathrm{P}, \mathrm{S}$ & ATRCAACCNCCRCGCCACAT & Winkler et al. 2009 \\
\hline
\end{tabular}


Table 4. Fergusoninid species (as defined in methods) arranged by alphabetized host plant name(s). "Species" number is an arbitrary designation based upon the order of appearance in this table. $\mathrm{N}$ is number of specimens in the species limits analysis. PWD\% refers to the average pairwise differences within each presumptive species represented by multiple individuals. Host plants may be listed multiple times for "oligophagous" species, and are followed by specimen codes. Gall Type indicates the type of gall from which specimens in any presumptive species were reared. "Species" number presented here is used throughout this article, including the Tables and Figures. Abbreviations for genera are as follows: $\mathrm{A}=$ Angophora, $\mathrm{C}=$ Corymbia, $\mathrm{E}=$ Eucalyptus, $\mathrm{L}=$ Leptospermum, Met=Metrosideros, $\mathrm{M}=$ Melaleuca, $\mathrm{S}=$ Sygyzium.

\begin{tabular}{|c|c|c|c|c|}
\hline $\begin{array}{c}\text { "Species" } \\
\text { No. } \\
\end{array}$ & $\mathbf{N}$ & $\begin{array}{c}\text { PWD } \\
(\%) \\
\end{array}$ & Host Plants and Fly Specimen codes & Gall Type \\
\hline $\mathrm{Sp} \# 1$ & 1 & -- & A. floribunda: FC-144 & M-Shoot Bud \\
\hline $\mathrm{Sp} \# 2$ & 1 & -- & C. abbreviata: FC-104 & M-Flower Bud \\
\hline $\mathrm{Sp} \# 3$ & 3 & 0.8 & $\begin{array}{l}\text { C. citriodora: } \mathrm{FC}-762 \\
\text { C. variegata: } \mathrm{FC}-761, \mathrm{FC}-763\end{array}$ & M-Shoot Bud \\
\hline $\mathrm{Sp} \# 4$ & 1 & -- & C. citriodora: $\mathrm{FC}-80$ & Leaf Peagall \\
\hline $\mathrm{Sp} \# 5$ & 6 & 0.3 & C. ptychocarpa: FC-26, FC-27, FC-36, FC-48, FCV-180, FCV-201 & M-Flower Bud \\
\hline $\mathrm{Sp} \# 6$ & 5 & 1.4 & C. tessellaris: FC-100, FC-731, FC-171, FC-771, FC-774 & M-Shoot Bud \\
\hline $\mathrm{Sp} \# 7$ & 1 & -- & C. tessellaris: FC-735 & M-Shoot Bud \\
\hline $\mathrm{Sp} \# 8$ & 1 & -- & C. torrelliana: FC-760 & U-Stem \\
\hline $\mathrm{Sp} \# 9$ & 1 & -- & Corymbia sp.: FC-79 & Leaf Peagall \\
\hline $\mathrm{Sp} \# 10$ & 1 & -- & E. acmenioides: FC-733 & M-Shoot Bud \\
\hline Sp \#11 & 3 & 2.0 & $\begin{array}{l}\text { E. amygdalina: } \mathrm{FCV}-148 \\
\text { E. coccifera: } \mathrm{FC}-603 \\
\text { E. stellulata: } \mathrm{FC}-544\end{array}$ & M-Shoot Bud \\
\hline Sp \#12 & 1 & -- & E. baxteri: FC-186 & M-Flower Bud \\
\hline Sp \#13 & 6 & 0.4 & $\begin{array}{l}\text { E. blakelyi: FC- } 143 \\
\text { E. camaldulensis: FC- } 61, \text { FC- } 73 \text {, FC- } 118, \text { FCV-204 }\end{array}$ & M-Shoot Bud \\
\hline
\end{tabular}




\begin{tabular}{|c|c|c|c|c|}
\hline & & & E. dealbata: $\mathrm{FC}-775$ & \\
\hline Sp \#14 & 1 & -- & E. camaldulensis: FC-736 & M-Shoot Bud \\
\hline $\mathrm{Sp} \# 15$ & 1 & -- & E. camaldulensis: FC-740 & M-Shoot Bud \\
\hline $\mathrm{Sp} \# 16$ & 1 & -- & E. camaldulensis: FC-105 & M-Flower Bud \\
\hline Sp \#17 & 15 & 0.7 & $\begin{array}{l}\text { E. coccifera: FC-541, FC-543, FC-602, FC-606, FC-608 } \\
\text { E. niphophila: FC-521, FC-522, FC-526, FC-586 } \\
\text { E. pauciflora: FC-515, FC-539, FC-609, FC-610, FC-618, FC-619 }\end{array}$ & M-Shoot Bud \\
\hline Sp \#18 & 5 & 0.8 & $\begin{array}{l}\text { E. cosmophylla: FCV-114, FC- } 177 \\
\text { E. tereticornis: FC-134, FC-169, FCV-199 }\end{array}$ & M-Shoot Bud \\
\hline Sp \#19 & 1 & -- & E. gomphocephala: FC-113 & Leaf Peagall \\
\hline Sp \#20 & 2 & 1.2 & $\begin{array}{l}\text { E. haemastoma: } \mathrm{FCV}-194 \\
\text { E. racemosa: } \mathrm{FC}-37\end{array}$ & M-Shoot Bud \\
\hline Sp \#21 & 2 & 0.0 & E. largiflorens: FC-910, FC-911 & M-Flat Leaf \\
\hline Sp \#22 & 2 & 0.5 & $\begin{array}{l}\text { E. leucoxylon: FC- } 755 \\
\text { E. nr. siderophloia: } \text { FC- } 741\end{array}$ & M-Flat Leaf \\
\hline Sp \#23 & 5 & 0.5 & $\begin{array}{l}\text { E. leucoxylon: } \mathrm{FC}-19, \mathrm{FC}-74, \mathrm{FC}-85 \\
\text { E. obliqua: } \mathrm{FC}-120 \\
\text { E. porosa: } \mathrm{FC}-142\end{array}$ & M-Flat Leaf \\
\hline Sp \#24 & 3 & 1.5 & $\begin{array}{l}\text { E. leucoxylon: FC- } 754 \\
\text { E. melliodora: FC- } 742 \\
\text { E. sp.: FC- } 145\end{array}$ & M-Flat Leaf \\
\hline Sp \#25 & 3 & 0.3 & E. macrorrhyncha: FC-64, FC-71, FC-88 & M-Flower Bud \\
\hline $\mathrm{Sp} \# 26$ & 1 & -- & E. mannifera: FC-753 & U-Peagall \\
\hline Sp \#27 & 1 & -- & E. marginata: FC-107 & Leaf Peagall \\
\hline $\mathrm{Sp} \# 28$ & 1 & -- & E. microcarpa: FC-173 & Leaf Peagall \\
\hline Sp \#29 & 1 & -- & E. microcarpa: FC-78 & M-Flower Bud \\
\hline Sp \#30 & 1 & -- & E. microcarpa: FC-188 & U-Peagall \\
\hline $\mathrm{Sp} \# 31$ & 5 & 0.5 & $\begin{array}{l}\text { E. niphophila: } \mathrm{FC}-724, \mathrm{FC}-725 \text { FC-750 } \\
\text { E. pauciflora: } \mathrm{FC}-535, \text { FC-540 }\end{array}$ & M-Flower Bud \\
\hline Sp \#32 & 8 & 1.5 & $\begin{array}{l}\text { E. niphophila: FC-523, FC-580 BT, FC-649, FC-652, FC-659 } \\
\text { E. pauciflora: FC-529, FC-632, FC-633 }\end{array}$ & M-Shoot Bud \\
\hline
\end{tabular}




\begin{tabular}{|c|c|c|c|c|}
\hline Sp \#33 & 1 & -- & E. obliqua: FC-737 & M-Shoot Bud \\
\hline $\mathrm{Sp} \# 34$ & 1 & -- & E. obliqua: FC-83 & M-Flower Bud \\
\hline Sp \#35 & 2 & 0.0 & E. odorata: FC-189, FC-190 & M-Flat Leaf \\
\hline Sp \#36 & 2 & 0.6 & E. pauciflora: FC-710, FC-711 & M-Shoot Bud \\
\hline Sp \#37 & 5 & 0.8 & E. pauciflora: FC-503, FC-506, FC-509, FC-510, FC-512 & M-Shoot Bud \\
\hline Sp \#38 & 2 & 0.3 & E. pauciflora: $\mathrm{FC}-508, \mathrm{FC}-718$ & M-Flower Bud \\
\hline Sp \#39 & 2 & 0.8 & E. pauciflora: FC-721, FC-720 & M-Flower Bud \\
\hline $\mathrm{Sp} \# 40$ & 3 & 0.2 & E. pauciflora: FC-147, FC-511, FC-716 & Leaf Peagall \\
\hline Sp \#41 & 1 & -- & E. pruinosa: $\mathrm{FC}-102$ & M-Flower Bud \\
\hline $\mathrm{Sp} \# 42$ & 1 & -- & E. robusta: $\mathrm{FC}-172$ & M-Shoot Bud \\
\hline $\mathrm{Sp} \# 43$ & 2 & 0.0 & E. siderophloia: $\mathrm{FC}-29, \mathrm{FC}-39$ & M-Flat Leaf \\
\hline Sp \#44 & 1 & -- & E. siderophloia: $\mathrm{FC}-89$ & M-Flat Leaf \\
\hline $\mathrm{Sp} \# 45$ & 1 & -- & E. stellulata: $\mathrm{FC}-751$ & M-Flower Bud \\
\hline Sp \#46 & 2 & 0.1 & E. tereticornis FC-757, FC-758 & M-Flower Bud \\
\hline Sp \#47 & 1 & -- & E. tereticornis: FC-780 & Leaf Peagall \\
\hline $\mathrm{Sp} \# 48$ & 1 & & E. melliodora: $\mathrm{FC}-743$ & U-Peagall \\
\hline Sp \#49 & 1 & -- & E. viminalis: FC-739 & U-Peagall \\
\hline $\mathrm{Sp} \# 50$ & 1 & -- & E. viminalis: $\mathrm{FC}-738$ & U-Peagall \\
\hline Sp \#51 & 2 & 0.5 & E. viminalis: $\mathrm{FC}-121, \mathrm{FC}-146$ & M-Shoot Bud \\
\hline Sp \#52 & 1 & -- & Eucalyptus sp.: FC-773 & M-Flat Leaf \\
\hline Sp \#53 & 1 & -- & Eucalyptus sp.: FC-778 & U-Peagall \\
\hline Sp \#54 & 1 & -- & Eucalyptus sp.: FC-748 & U-Peagall \\
\hline Sp \#55 & 2 & 0.0 & Eucalyptus sp.: FC-719, FC-746 & M-Flower Bud \\
\hline $\mathrm{Sp} \# 56$ & 1 & & Eucalyptus sp.: FC-756 & M-Shoot Bud \\
\hline Sp \#57 & 2 & 0.3 & Eucalyptus sp.: FC-98, FC-777 & $\begin{array}{l}\text { M-Shoot Bud, M-Flat } \\
\text { Leaf }\end{array}$ \\
\hline $\mathrm{Sp} \# 58$ & 1 & -- & L. madidum: FC-914 & M-Shoot Bud \\
\hline $\mathrm{Sp} \# 59$ & 2 & 0.0 & L. laevigatum: FC-912, FC-913 & U-Peagall \\
\hline $\mathrm{Sp} \# 60$ & 4 & 0.2 & Met. excelsa: FC-131, FC-132, FCV-198, FC-764 & M-Shoot Bud \\
\hline $\mathrm{Sp} \# 61$ & 1 & -- & M. argentea: FC- 184 & M-Shoot Bud \\
\hline Sp \#62 & 1 & -- & M. armillaris: $\mathrm{FC}-135$ & U-Peagall \\
\hline
\end{tabular}




\begin{tabular}{|c|c|c|c|c|}
\hline Sp \#63 & 6 & 0.3 & M. cajuputi: FC-24, FC-25, FC-35, FC-42, FC-53, FC-91 & M-Shoot Bud \\
\hline Sp \#64 & 6 & 0.8 & M. dealbata: FC-23, FC-30, FC-34, FC-40, FC-46, FC-732 & M-Shoot Bud \\
\hline Sp \#65 & 3 & 0.6 & $\begin{array}{l}\text { M. decora: } \mathrm{FC}-140, \text { FC- } 730 \\
\text { M. linariifolia: } \text { FC- } 759\end{array}$ & U-Peagall \\
\hline Sp \#66 & 4 & 0.0 & M. fluviatilis: FC-47, FC-55, FC-75, FC-93 & M-Shoot Bud \\
\hline Sp \#67 & 5 & 0.0 & M. fluviatilis: FC-21, FC-43, FC-92, FC-110, FCV-124 & M-Shoot Bud \\
\hline Sp \#68 & 5 & 0.5 & M. leucandendra: FC-22, FC-33, FC-52, FC-94, FC-95 & M-Shoot Bud \\
\hline Sp \#69 & 2 & 0.2 & M. linariifolia: FC-137, FC-170 & U-Peagall \\
\hline Sp \#70 & 2 & 0.9 & M. nervosa: FC-76, FC-84 & M-Shoot Bud \\
\hline Sp \#71 & 2 & 0.0 & M. nervosa: FC-31, FC-41 & M-Shoot Bud \\
\hline Sp \#72 & 1 & -- & M. nodosa: FC-136 & U-Peagall \\
\hline Sp \#73 & 4 & 0.7 & M. quinquenervia: FC-101, FC-122, FC-127, FC-183 & M-Shoot Bud \\
\hline Sp \#74 & 5 & 1.8 & M. quinquenervia: FC-20, FC-38, FC-45, FC-152, FCV-203 & M-Shoot Bud \\
\hline Sp \#75 & 1 & -- & M. quinquenervia $\mathrm{FCV}-123$ & M-Flower Bud \\
\hline Sp \#76 & 4 & 0.2 & M. stenostachya: FC-67, FC-77, FC-108, FC-109 & M-Shoot Bud \\
\hline Sp \#77 & 2 & 0.0 & M. viridiflora: $\mathrm{FC}-68, \mathrm{FC}-81$ & M-Shoot Bud \\
\hline $\mathrm{Sp} \# 78$ & 1 & -- & S. luehmannii: FC-734 & Mix of Galls \\
\hline Sp \#79 & 3 & 0.0 & S. luehmannii: FC-139, FCV-196, FCV-200 & Mix of Galls \\
\hline Sp \#80 & 4 & 1.1 & E. diversifolia: FC-18, FC-70, FC-915, FC-916 & M-Shoot Bud \\
\hline $\mathrm{Sp} \# 81$ & 1 & -- & Eucalyptus sp.: FC-779 & M-Flat Leaf \\
\hline $\mathrm{Sp} \# 82$ & 1 & -- & Eucalyptus sp.: FC-749 & U-Peagall \\
\hline Sp \#83 & 1 & -- & Eucalyptus sp.: FC-99 & Leaf Peagall \\
\hline $\mathrm{Sp} \# 84$ & 1 & -- & E. polyanthemos: FC-745 & M-Flat Leaf \\
\hline Sp. \#85 & 1 & -- & E. coccifera: FC-542 & Leaf Peagall \\
\hline
\end{tabular}


Table 5. Host species, Gall Type, and maximum pairwise distance of eleven presumptive fergusoninid species using a monophyly + $2 \%$ pairwise distance criterion (see also Fig. 2, dark blue clusters). Species identification number as given in Table 4.

\begin{tabular}{|c|c|c|c|c|c|}
\hline $\begin{array}{l}\text { Species } \\
\text { No. }\end{array}$ & Host Plant (Fly Specimens) & $\begin{array}{l}\text { Eucalyptus } \\
\text { Subgenus }\end{array}$ & $\begin{array}{l}\text { Max. PW } \\
\text { Distance }\end{array}$ & Gall & Locations \\
\hline Sp. \#65 & $\begin{array}{l}\text { M. decora, } \mathrm{FC}-730, \mathrm{FC}-140 \\
\text { M. linariifolia, } \mathrm{FC}-759\end{array}$ & -- & 0.6 & $\begin{array}{l}\text { U-PG } \\
\text { U-PG }\end{array}$ & QLD \\
\hline Sp. \#3 & $\begin{array}{l}\text { C. citriodora, } \mathrm{FC}-761, \mathrm{FC}-763 \\
\text { C. maculata, } \mathrm{FC}-762\end{array}$ & -- & 0.8 & $\begin{array}{l}\text { Shoot Bud } \\
\text { Shoot Bud }\end{array}$ & NSW \\
\hline Sp. \#32 & $\begin{array}{l}\text { E. pauciflora, FC-529, FC-632, FC-633 } \\
\text { E. niphophila FC-523, FC-580, FC-649, FC-652, FC-659 }\end{array}$ & $\begin{array}{l}\text { Eucalyptus } \\
\text { Eucalyptus }\end{array}$ & 1.5 & $\begin{array}{l}\text { Shoot Bud } \\
\text { Shoot Bud }\end{array}$ & NSW, VIC \\
\hline Sp. \#20 & $\begin{array}{l}\text { E. haemastoma, FCV-194 } \\
\text { E. racemosa, FC- } 37\end{array}$ & $\begin{array}{l}\text { Eucalyptus } \\
\text { Eucalyptus }\end{array}$ & 1.2 & $\begin{array}{l}\text { Shoot Bud } \\
\text { Shoot Bud }\end{array}$ & NSW. QLD \\
\hline Sp. \#17 & $\begin{array}{l}\text { E. niphophila, FC-521, FC-522, FC-526, FC-586 } \\
\text { E. coccifera, FC-541, FC-543, FC-602, FC-606, FC-608 } \\
\text { E. pauciflora, FC-515, FC-539, FC-609, FC-610, FC-618, FC- } \\
619\end{array}$ & $\begin{array}{l}\text { Eucalyptus } \\
\text { Eucalyptus } \\
\text { Eucalyptus }\end{array}$ & 1.7 & $\begin{array}{l}\text { Shoot Bud } \\
\text { Shoot Bud } \\
\text { Shoot Bud }\end{array}$ & ACT, TAS, VIC \\
\hline Sp. \#11 & $\begin{array}{l}\text { E. amygdalina, } \mathrm{FCV}-148 \\
\text { E. stellulata, } \mathrm{FC}-544 \\
\text { E. coccifera, } \mathrm{FC}-603\end{array}$ & $\begin{array}{l}\text { Eucalyptus } \\
\text { Eucalyptus } \\
\text { Eucalyptus }\end{array}$ & 1.9 & $\begin{array}{l}\text { Shoot Bud } \\
\text { Shoot Bud } \\
\text { Shoot Bud }\end{array}$ & ACT, TAS \\
\hline Sp. \#31 & $\begin{array}{l}\text { E. pauciflora, FC-535, FC-540 } \\
\text { E. niphophila, FC-724, FC-725, FC-750 }\end{array}$ & $\begin{array}{l}\text { Eucalyptus } \\
\text { Eucalyptus } \\
\end{array}$ & 0.5 & $\begin{array}{l}\text { Flower Bud } \\
\text { Flower Bud }\end{array}$ & NSW, TAS, VIC \\
\hline Sp. \#23 & $\begin{array}{l}\text { E. leucoxylon, } \mathrm{FC}-19, \mathrm{FC}-74, \mathrm{FC}-85, \mathrm{FC}-120 \\
\text { E. porosa, } \mathrm{FC}-142\end{array}$ & $\begin{array}{l}\text { Symphyomyrtus } \\
\text { Symphyomyrtus }\end{array}$ & 0.5 & $\begin{array}{l}\text { Flat Leaf } \\
\text { Flat Leaf }\end{array}$ & $\mathrm{SA}$ \\
\hline Sp. \#24 & $\begin{array}{l}\text { E. leucoxylon, } \mathrm{FC}-754 \\
\text { E. melliodora, } \mathrm{FC}-742 \\
\text { Eucalyptus } \text { sp., } \mathrm{FC}-145\end{array}$ & $\begin{array}{l}\text { Symphyomyrtus } \\
\text { Symphyomyrtus } \\
--\end{array}$ & 1.5 & $\begin{array}{l}\text { Flat Leaf } \\
\text { Flat Leaf } \\
\text { Flat Leaf }\end{array}$ & $\mathrm{ACT}$ \\
\hline Sp. \#13 & $\begin{array}{l}\text { E. blakelyi, FC- } 143 \\
\text { E. camaldulensis, FC-118, FCV-204 } \\
\text { E. dealbata, FC- } 775 \\
\text { E. intertexta, FC- } 61, \mathrm{FC}-73\end{array}$ & $\begin{array}{l}\text { Symphyomyrtus } \\
\text { Symphyomyrtus } \\
\text { Symphyomyrtus } \\
\text { Symphyomyrtus }\end{array}$ & 0.8 & $\begin{array}{l}\text { Shoot Bud } \\
\text { Shoot Bud } \\
\text { Shoot Bud } \\
\text { Shoot Bud }\end{array}$ & ACT, NSW, SA \\
\hline Sp. \#18 & $\begin{array}{l}\text { E. cosmophylla, FC-114, FCV-177 } \\
\text { E. tereticornis, FC-134, FC-169, FCV-199 }\end{array}$ & $\begin{array}{l}\text { Symphyomyrtus } \\
\text { Symphyomyrtus }\end{array}$ & 0.8 & $\begin{array}{l}\text { Shoot Bud } \\
\text { Shoot Bud }\end{array}$ & SA \\
\hline
\end{tabular}


Table 6. Contingency test of independence between dietary specialization (monophagous vs. oligophagous) and a) host genus (Eucalyptus vs. Other Genera); b) gall type (Shoot Bud Galls vs. Other Gall Types); and c) phylogenetic placement (Clade C+D vs Other Clades; see text, Figure 5). Only Fergusonina species having more than one representative are included.

a) Host genus and dietary specialization. Chi-sq=4.0529, $\mathrm{df}=1, \mathrm{p}=0.044 *$.

\begin{tabular}{|l|c|c|c|}
\hline Contrast & Monophagous & Oligophagous & Total \\
\hline & & & \\
\hline Eucalyptus & 15 & 9 & 24 \\
\hline Other Genera & 17 & 2 & 19 \\
\hline & 32 & 11 & 43 \\
\hline
\end{tabular}

b) Gall type and dietary specialization. Chi-sq $0.1813, \mathrm{df}=1, \mathrm{p}=0.670$.

\begin{tabular}{|l|c|c|c|}
\hline Contrast & Monophagous & Oligophagous & Total \\
\hline Shoot Bud Galls & & & \\
\hline Other Gall Types & 7 & 7 & 24 \\
\hline Total & 24 & 4 & 11 \\
\hline
\end{tabular}

c) Phylogenetic placement and dietary specialization. Chi-sq=19.01, $\mathrm{df}=1, \mathrm{p}<0.0001 * * *$.

\begin{tabular}{|l|c|c|c|}
\hline Contrast & Monophagous & Oligophagous & Total \\
\hline & & & \\
\hline Clade C+D & 5 & 6 & 11 \\
\hline Other Clades & 68 & 5 & 73 \\
\hline Total & 73 & 11 & 84 \\
\hline
\end{tabular}


Table 7. The plant host species and their Fergusonina species used in this study. The fly species numbers used throughout this study are in the second column (defined in Table 4). Gall type, the samples size of fly specimens on that host species, and their specimen codes are shown. For host plants fed upon by "oligophagous" fergusoninid species, the additional host(s) and the code numbers of specimens from these are given.are listed. Fergusonina species name given for described species; " $F$. n. sp." indicates that flies from that gall type and plant host (often from the same collection) have been determined to be new; " $F$. unknown" is given for those species having undetermined status.

\begin{tabular}{|c|c|c|c|c|c|c|}
\hline Host Plant & $\begin{array}{c}\text { Fly } \\
\text { Sp. \# }\end{array}$ & Gall Type & $\mathbf{N}$ & $\begin{array}{l}\text { Fergusonina } \\
\text { Specimens } \\
\end{array}$ & Additional Hosts & Fergusonina species \\
\hline \multicolumn{7}{|l|}{ Angophora } \\
\hline \multirow[t]{2}{*}{ A. floribunda } & 1 & M-Shoot Bud & 1 & FC-144 & -- & $\begin{array}{l}F . \text { n. sp. (Davies et al. } \\
\text { 2013a, pg. 133) }\end{array}$ \\
\hline & & & & & -- & \\
\hline Corymbia & & & & & -- & \\
\hline C. abbreviata & 2 & M-Flower Bud & 1 & FC-104 & & F. thomasi Taylor \\
\hline \multirow[t]{2}{*}{ C. maculata } & 3 & M-Shoot Bud & 2 & FC-762, FC-761 & $\begin{array}{l}\text { C. citriodora: FC- } \\
763\end{array}$ & F. biseta Tonnoir \\
\hline & 4 & Leaf Peagall & 1 & FC- 80 & -- & $F$. unknown \\
\hline C. ptychocarpa & 5 & M-Flower Bud & 6 & $\begin{array}{l}\text { FCV-201, FCV-180, } \\
\text { FC-27, FC-26, FC- } \\
36, \text { FC-48 }\end{array}$ & -- & F. giblindavisi Taylor \\
\hline \multirow[t]{2}{*}{ C. tessellaris } & 6 & M-Shoot Bud & 5 & $\begin{array}{l}\text { FC-100, FC-731, } \\
\text { FC-771, FC-774, FC- } \\
171\end{array}$ & -- & $\begin{array}{l}F . \text { n. sp. (Davies et al. } \\
\text { 2010a, pg. 22) }\end{array}$ \\
\hline & 7 & M-Shoot Bud & 1 & FC-735 & -- & $\begin{array}{l}F \text {. n. sp. (Davies et al. } \\
\text { 2010a, pg. 22) }\end{array}$ \\
\hline C. torelliana & 8 & U-Stem & 1 & FC-760 & -- & F. unknown \\
\hline C. citriodora & 1 & M-Shoot Bud & 1 & FC-763 & $\begin{array}{l}\text { C. maculata: FC- } \\
762, \text { FC-761 }\end{array}$ & $F$. unknown \\
\hline
\end{tabular}




\begin{tabular}{|c|c|c|c|c|c|c|}
\hline Corymbia sp. & 9 & Leaf Peagall & 1 & FC-79 & -- & F. unknown \\
\hline \multicolumn{7}{|l|}{ Eucalyptus } \\
\hline E. acmenioides & 10 & M-Shoot Bud & 1 & FC-733 & -- & $\begin{array}{l}\text { F. n. sp. (Davies et al. } \\
\text { 2010b, pg. 23; Davies et } \\
\text { al. 2013a, pg. 133) }\end{array}$ \\
\hline E. amygdalina & 11 & M-Shoot Bud & 1 & FC-148 & $\begin{array}{l}\text { E. stellulata: FC- } \\
544 \text {, E. coccifera: } \\
\text { FC-603 }\end{array}$ & $\begin{array}{l}F . \text { n. sp. (Davies et al. } \\
\text { 2010b, pg. 23) }\end{array}$ \\
\hline E. baxteri & 12 & M-Flower Bud & 1 & FC-186 & -- & $\begin{array}{l}\text { F. n. sp. (Davies et al. } \\
\text { 2012b, pg. 29) }\end{array}$ \\
\hline E. blakelyi & 13 & M-Shoot Bud & 1 & FC-143 & $\begin{array}{l}\text { E. camaldulensis: } \\
\text { FCV-204, FC-118, } \\
\text { FC-61, FC-73; E. } \\
\text { dealbata: FC-776, }\end{array}$ & $\begin{array}{l}\text { F. n. sp. (Davies et al., } \\
\text { 2013b, pg.133) }\end{array}$ \\
\hline \multirow[t]{4}{*}{ E. camaldulensis } & 13 & M-Shoot Bud & 2 & $\begin{array}{l}\text { FCV-204, FC-61, } \\
\text { FC-73 }\end{array}$ & $\begin{array}{l}\text { E. blakelyi: } F C-143 \\
\text { E. dealbata: } \mathrm{FC}-776\end{array}$ & $\begin{array}{l}F . \text { n. sp. (Davies et al } \\
\text { 2013a, pg. 133) }\end{array}$ \\
\hline & 14 & M-Shoot Bud & 1 & FC-736 & -- & F. lockharti Tonnoir \\
\hline & 15 & M-Shoot Bud & 1 & FC-740 & -- & F. lockharti Tonnoir \\
\hline & 16 & M-Flower Bud & 1 & FC-105 & -- & F. tillyardi Tonnoir \\
\hline \multirow[t]{3}{*}{ E. coccifera } & 85 & Leaf Peagall & 1 & FC-542 & -- & $F$. unknown \\
\hline & 17 & M-Shoot Bud & 5 & $\begin{array}{l}\text { FC-541, FC-543, } \\
\text { FC-602, FC-606, FC- } \\
608\end{array}$ & $\begin{array}{l}\text { E. niphophila: FC- } \\
586, \text { FC-521, FC- } \\
526, \text { FC-522; } \text {. } \\
\text { pauciflora: FC-515, } \\
\text { FC-618, FC-619, } \\
\text { FC-539, FC-610, } \\
\text { FC-609 }\end{array}$ & $\begin{array}{l}\text { F. taylori Nelson and } \\
\text { Yeates }\end{array}$ \\
\hline & 11 & M-Shoot Bud & 1 & FC-603 & $\begin{array}{l}\text { E. amygdalina: } \\
F C V-148 ; E \text {. }\end{array}$ & F. unknown \\
\hline
\end{tabular}




\begin{tabular}{|c|c|c|c|c|c|c|}
\hline & \\
\hline E. cosmophylla & 18 & M-Shoot Bud & 2 & FCV-114, FC-177 & $\begin{array}{l}\text { stellulata: FC-544 } \\
\text { E. tereticornis: FC- } \\
\text { 169, FC-134, FCV- } \\
199\end{array}$ & $\begin{array}{l}F . \text { n. sp. Davies et al. } \\
2013 \text { a, pg. } 133\end{array}$ \\
\hline E. dealbata & 13 & M-Shoot Bud & 1 & FC-776 & $\begin{array}{l}\text { E. blakelyi: FC-143; } \\
\text { E. camaldulensis: } \\
\text { FCV-204, FC-118, } \\
\text { FC-61, FC-73, }\end{array}$ & $\begin{array}{l}\text { F. n. sp. (Davies et al } \\
\text { 2013a, pg. 133) }\end{array}$ \\
\hline E. diversifolia & 80 & M-Shoot Bud & 4 & $\begin{array}{l}\text { FC-18, FC-70, FC- } \\
915, \text { FC-916 }\end{array}$ & -- & $\begin{array}{l}F . \text { n. sp. (Davies et al. } \\
\text { 2013a, pg. 133) }\end{array}$ \\
\hline $\begin{array}{l}\text { E. } \\
\text { gomphocephala }\end{array}$ & 19 & Leaf Peagall & 1 & FC-113 & -- & F. newmani Tonnoir \\
\hline E. haemastoma & 20 & M-Shoot Bud & 1 & FCV-194 & E. racemosa: $F C-37$ & $\begin{array}{l}F . \text { n. sp. (Davies et al. } \\
\text { 2013a, pg. 133) }\end{array}$ \\
\hline E. largiflorens & 21 & M-Flat Leaf & 2 & FC-910, FC-911 & -- & $F$. unknown \\
\hline \multirow[t]{3}{*}{ E. leucoxylon } & 22 & M-Flat Leaf & 1 & FC-755 & -- & $\begin{array}{l}F . \text { n. sp. ( Davies and } \\
\text { Lloyd } 1996, \text { pg. } 17 \text { ) }\end{array}$ \\
\hline & 23 & M-Flat Leaf & 3 & FC-19, FC-74, FC-85 & $\begin{array}{l}\text { E. obliqua: FC- } 120 \text {, } \\
\text { E. porosa: FC- } 142\end{array}$ & $F$. unknown \\
\hline & 24 & M-Flat Leaf & 1 & FC-754 & $\begin{array}{l}\text { E. melliodora: FC- } \\
742\end{array}$ & $F$. unknown \\
\hline $\begin{array}{l}\text { E. } \\
\text { macrorrhyncha }\end{array}$ & 25 & M-Flower Bud & 3 & FC-64, FC-71, FC-88 & -- & F. nicholsoni Tonnoir \\
\hline E. mannifera & 26 & U-Peagall & 1 & FC-753 & -- & $F$. unknown \\
\hline E. marginata & 27 & Leaf Peagall & 1 & FC-107 & -- & $\begin{array}{l}F . \text { n. sp. (Davies et al. } \\
\text { 2010b, pg. 24) }\end{array}$ \\
\hline E. melliodora & 48 & U-Peagall & 1 & FC-743 & -- & $F$. unknown \\
\hline E. melliodora & 24 & M-Flat Leaf & 1 & FC-742 & $\begin{array}{l}\text { E. leucoxylon: FC- } \\
754\end{array}$ & $F$. unknown \\
\hline \multirow[t]{3}{*}{ E. microcarpa } & 28 & Leaf Peagall & 1 & FC-173 & -- & $\begin{array}{l}F . \text { n. sp. (Davies et al. } \\
2014 \text { c, pg. } 168 \text { ) }\end{array}$ \\
\hline & 29 & M-Flower Bud & 1 & FC-78 & -- & $\begin{array}{l}F . \text { n. sp. (Davies et al. } \\
2012 \text { b, pg. } 30 \text { ) }\end{array}$ \\
\hline & 30 & U-Peagall & 1 & FC-188 & -- & F. n. sp. (Davies et al. \\
\hline
\end{tabular}




\begin{tabular}{|c|c|c|c|c|c|c|}
\hline \multirow{4}{*}{ E. niphophila } & & & & & & 2010b, pg. 35) \\
\hline & 31 & M-Flower Bud & 3 & $\begin{array}{l}\text { FC-724, FC-725, FC- } \\
750,\end{array}$ & $\begin{array}{l}\text { E. pauciflora: FC- } \\
535 \text {, FC- } 540\end{array}$ & $F$. unknown \\
\hline & 32 & M-Shoot Bud & 5 & $\begin{array}{l}\text { FC-523, FC-580, } \\
\text { FC-652, FC-659, }\end{array}$ & $\begin{array}{l}\text { E. pauciflora: FC- } \\
529, \text { FC-632, FC- } \\
633\end{array}$ & $\begin{array}{l}\text { F. daviesae Nelson and } \\
\text { Yeates }\end{array}$ \\
\hline & 17 & M-Shoot Bud & 5 & $\begin{array}{l}\text { FC-515, FC-521, } \\
\text { FC-586, FC-526, FC- } \\
522,\end{array}$ & $\begin{array}{l}\text { E. coccifera: FC- } \\
608, \text { FC-602, FC- } \\
543, \text { FC-606, FC- } \\
541 ; \text { E. pauciflora; } \\
\text { FC-515, FC-618, } \\
\text { FC-619, FC-539, } \\
\text { FC-610, FC-609 }\end{array}$ & $\begin{array}{l}\text { F. taylori Nelson and } \\
\text { Yeates }\end{array}$ \\
\hline \multirow[t]{3}{*}{ E. obliqua } & 33 & M-Shoot Bud & 1 & FC-737 & -- & $\begin{array}{l}\text { F. n. sp. (Davies et al. } \\
\text { 2013a, pg. 133) }\end{array}$ \\
\hline & 23 & M-Flat Leaf & 1 & FC-120 & $\begin{array}{l}\text { E. leucoxylon: FC- } \\
\text { 19, FC- } 85 \text {, FC-74; } \\
\text { E. porosa: FC-142 }\end{array}$ & $F$. unknown \\
\hline & 34 & M-Flower Bud & 1 & FC-83 & -- & $\begin{array}{l}\text { F. n. sp. (Davies et al. } \\
\text { 2010b, pg. 26) }\end{array}$ \\
\hline E. odorata & 35 & M-Flat Leaf & 2 & FC-189, FC-190 & -- & $\begin{array}{l}F . \text { n. sp. (Davies et al. } \\
\text { 2013b, pg. } 168 \text { ) }\end{array}$ \\
\hline \multirow[t]{3}{*}{ E. pauciflora } & 17 & M-Shoot Bud & 6 & $\begin{array}{l}\text { FC-515, FC-618, FC- } \\
619, \text { FC-539, FC- } \\
610, \text { FC-609 }\end{array}$ & $\begin{array}{l}\text { E. coccifera: FC- } \\
608, \text { FC-602, FC- } \\
\text { 543, FC-606, FC- } \\
541 ; \text { E. niphophila: } \\
\text { FC-515, FC-521, } \\
\text { FC-586, FC-526, } \\
\text { FC-522 }\end{array}$ & $\begin{array}{l}\text { F. taylori Nelson and } \\
\text { Yeates }\end{array}$ \\
\hline & 37 & M-Shoot Bud & 2 & $\begin{array}{l}\text { FC-500, FC-503, FC- } \\
506, \text { FC-509, FC- } \\
510, \text { FC-512 }\end{array}$ & -- & $\begin{array}{l}\text { F. omlandi Nelson and } \\
\text { Yeates }\end{array}$ \\
\hline & 32 & M-Shoot Bud & 3 & $\begin{array}{l}\text { FC-529, FC-632, FC- } \\
633\end{array}$ & $\begin{array}{l}\text { E. niphophila: FC- } \\
\text { 523, FC-580, FC- }\end{array}$ & $\begin{array}{l}\text { F. daviesae Nelson and } \\
\text { Yeates }\end{array}$ \\
\hline
\end{tabular}




\begin{tabular}{|c|c|c|c|c|c|c|}
\hline & & & & & 652, FC-659 & \\
\hline & 36 & M-Shoot Bud & 2 & FC-710, FC-711 & -- & $\begin{array}{l}\text { F. tasmaniensis Nelson } \\
\text { and Yeates }\end{array}$ \\
\hline & 38 & M-Flower Bud & 2 & FC-508, FC-718 & -- & $F$. unknown \\
\hline & 39 & M-Flower Bud & 2 & FC-721, FC-720 & -- & F. unknown \\
\hline & 31 & M-Flower Bud & 2 & FC-535, FC-540 & $\begin{array}{l}\text { E. niphophila: FC- } \\
724, \text { FC-725 FC- } \\
750 \text {, }\end{array}$ & F. unknown \\
\hline & 40 & Leaf Peagall & 3 & $\begin{array}{l}\text { FC-716, FC-147, FC- } \\
511\end{array}$ & -- & $F$. unknown \\
\hline E. polyanthemos & 85 & M-Flat Leaf & 1 & FC-745 & -- & $\begin{array}{l}F . \text { n. sp. (Davies et al. } \\
2013 \text { b, pg. 168) }\end{array}$ \\
\hline E. porosa & 23 & M-Flat Leaf & 1 & FC-142 & $\begin{array}{l}\text { E. leucoxylon: FC- } \\
\text { 19, FC-85, FC-74; } \\
\text { E. obliqua: FC-120 }\end{array}$ & $\begin{array}{l}\text { F. n. sp. (Davies et al. } \\
\text { 2013a, pg. 168) }\end{array}$ \\
\hline E. pruinosa & 41 & M-Flower Bud & 1 & FC-102 & -- & $\begin{array}{l}\text { F. n. sp. (Davies et al. } \\
2012 \text { b, pg. 29) }\end{array}$ \\
\hline E. racemosa & 20 & M-Shoot Bud & 1 & FC-37 & $\begin{array}{l}\text { E. haemastoma: } \\
\text { FCV-194 }\end{array}$ & $\begin{array}{l}\text { F. n. sp. (Davies et al., } \\
\text { 2013a, pg. 133) }\end{array}$ \\
\hline E. robusta & 42 & M-Shoot Bud & 1 & FC-172 & -- & \\
\hline \multirow[t]{2}{*}{ E. siderophloia } & 43 & M-Flat Leaf & 1 & FC-29 & -- & $\begin{array}{l}\text { F. n. sp. (Davies et al., } \\
\text { 2013b, pg. 168) }\end{array}$ \\
\hline & 44 & M-Flat Leaf & 1 & FC-89 & -- & $\begin{array}{l}F . \text { n. sp. (Davies et al., } \\
2013 \text { b, pg. } 168 \text { ) }\end{array}$ \\
\hline \multirow[t]{2}{*}{ E. stellulata } & 11 & M-Shoot Bud & 1 & FC-544 & $\begin{array}{l}\text { E. coccifera: } \mathrm{FC}- \\
603 ; \text { E. amygdalina: } \\
\text { FCV-148 }\end{array}$ & $F$. unknown \\
\hline & 45 & M-Flower Bud & 1 & FC-751 & -- & $F$. unknown \\
\hline \multirow[t]{3}{*}{ E. tereticornis } & 18 & M-Shoot Bud & 3 & $\begin{array}{l}\text { FC-169, FC-134, } \\
\text { FCV-199 }\end{array}$ & $\begin{array}{l}\text { E. cosmophylla: } \\
\text { FCV-114, FC-177 }\end{array}$ & $\begin{array}{l}\text { F. n. sp. (Davies et al., } \\
\text { 2013a, pg. 134) }\end{array}$ \\
\hline & 46 & M-Flower Bud & 2 & FC-757, FC-758 & -- & $F$. unknown \\
\hline & 47 & Leaf Peagall & 1 & FC-780 & -- & $F$. unknown \\
\hline E. viminalis & 51 & M-Shoot Bud & 2 & FC-121, FC-146 & -- & $\begin{array}{l}F . \text { n. sp. (Davies et al., } \\
\text { 2014a,pg. 552) }\end{array}$ \\
\hline
\end{tabular}




\begin{tabular}{|c|c|c|c|c|c|c|}
\hline & 50 & U-Peagall & 1 & FC-738 & $\overline{--}$ & $F$. unknown \\
\hline & 49 & U-Peagall & 1 & FC-739 & -- & $\begin{array}{l}F . \text { n. sp. (Davies et al., } \\
2014 \text { c, pg. 138) }\end{array}$ \\
\hline Eucalyptus sp. & 52 & M-Flat Leaf & 1 & FC-773 & -- & $F$. unknown \\
\hline Eucalyptus sp. & 53 & U-Peagall & 1 & FC-778 & -- & F. unknown \\
\hline Eucalyptus sp. & 54 & U-Peagall & 1 & FC-748 & -- & F. unknown \\
\hline Eucalyptus $s p$. & 55 & M-Flower Bud & 2 & FC-719, FC-746 & -- & F. unknown \\
\hline Eucalyptus sp. & 56 & M-Shoot Bud & 1 & FC-756 & -- & F. unknown \\
\hline Eucalyptus sp. & 57 & $\begin{array}{l}\text { M-Shoot Bud, } \\
\text { M-Flat Leaf }\end{array}$ & 1 & FC-777, FC-98 & -- & $F$. unknown \\
\hline Eucalyptus sp. & 81 & M-FLG & 1 & FC-779 & -- & F. unknown \\
\hline Eucalyptus sp. & 82 & U-Peagall & & FC-749 & -- & F. unknown \\
\hline Eucalyptus sp. & 83 & Leaf Peagall & 1 & FC-99 & -- & F. unknown \\
\hline Eucalyptus sp. & 84 & M-FLG & 1 & FC-745 & -- & $F$. unknown \\
\hline \multicolumn{7}{|l|}{ Leptospermum } \\
\hline L. madidum & 58 & M-Shoot Bud & 1 & FC-914 & -- & $F$. n. sp., Taylor in prep. \\
\hline L. laevigatum & 59 & U-Peagall & & FC-912, FC-913 & -- & $F$. n. sp., Taylor in prep. \\
\hline \multicolumn{7}{|l|}{ Metrosideros } \\
\hline Met. excelsa & 60 & M-Shoot Bud & 4 & $\begin{array}{l}\text { FC-131, FC-132, } \\
\text { FCV-198, FC-764 }\end{array}$ & -- & F. metrosiderosi Taylor \\
\hline \multicolumn{7}{|l|}{ Melaleuca } \\
\hline M. argentea & 61 & M-Shoot Bud & 1 & FC-184 & -- & $F$. unknown \\
\hline M. armillaris & 62 & U-Peagall & & FC-135 & -- & F. n. sp. Taylor 2004 \\
\hline M. cajuputi & 63 & M-Shoot Bud & 6 & $\begin{array}{l}\text { FC-24, FC-25, FC- } \\
35, \text { FC-42, FC-53, } \\
\text { FC-91 }\end{array}$ & -- & F. purcelli Taylor \\
\hline M. dealbata & 64 & M-Shoot Bud & 6 & $\begin{array}{l}\text { FC-23, FC-30, FC- } \\
34, \text { FC-40, FC-46, } \\
\text { FC-732 }\end{array}$ & -- & F. makinsoni Taylor 2004 \\
\hline
\end{tabular}




\begin{tabular}{|c|c|c|c|c|c|c|}
\hline M. decora & 65 & U-Peagall & 2 & FC-730, FC-140 & -- & $\begin{array}{l}F . \text { n. sp. (Davies et al., } \\
\text { 2014, pg. 254) }\end{array}$ \\
\hline \multirow[t]{2}{*}{ M. fluviatilis } & 66 & M-Shoot Bud & 4 & $\begin{array}{l}\text { FC-47, FC-55, FC- } \\
75, \text { FC-93 }\end{array}$ & -- & $\begin{array}{l}\text { Currently }[F \text {. turneri } \\
\text { Taylor 2004] }\end{array}$ \\
\hline & 67 & M-Shoot Bud & 5 & $\begin{array}{l}\text { FC-21, FC-43, FC- } \\
92, \text { FC-110, FCV- } \\
124\end{array}$ & -- & $\begin{array}{l}\text { Currently [F. turneri } \\
\text { Taylor 2004] }\end{array}$ \\
\hline M. leucandendra & 68 & M-Shoot Bud & 5 & $\begin{array}{l}\text { FC-22, FC-33, FC- } \\
52, \text { FC-95, FC-94 }\end{array}$ & -- & F. centeri Taylor 2004 \\
\hline \multirow[t]{2}{*}{ M. linariifolia } & 65 & U-Peagall & 1 & FC-759, & $\begin{array}{l}\text { E. decora: FC-140, } \\
\text { FC-730 }\end{array}$ & $\begin{array}{l}F . \text { n. sp. (Davies et al., } \\
2014 \text {, pg. 254) }\end{array}$ \\
\hline & 69 & U-Peagall & 2 & FC-137, FC-170 & -- & $\begin{array}{l}\text { F. n. sp. (Davies et al., } \\
2014, \text { pg. 254) }\end{array}$ \\
\hline \multirow[t]{2}{*}{ M. nervosa } & 70 & M-Shoot Bud & 2 & FC-76, FC-84 & -- & F. schefferae Taylor 2004 \\
\hline & 71 & M-Shoot Bud & 2 & FC-31, FC-41 & -- & F. goolsbyi Taylor 2004 \\
\hline M. nodosa & 72 & U-Peagall & 1 & FC-136 & -- & $\begin{array}{l}F . \text { n. sp. (Davies et al., } \\
2014, \text { pg. 254) }\end{array}$ \\
\hline \multirow[t]{3}{*}{$\begin{array}{l}\text { M. } \\
\text { quinquenervia }\end{array}$} & 73 & M-Shoot Bud & 4 & $\begin{array}{l}\text { FC-101, FC-122, FC- } \\
127, \text { FC-183 }\end{array}$ & -- & $F$. unknown \\
\hline & 74 & M-Shoot Bud & 6 & $\begin{array}{l}\text { FC-38, FC-45, FC- } \\
20, \text { FC-152, FCV- } \\
203\end{array}$ & -- & F. turneri Taylor 2004 \\
\hline & 75 & M-Flower Bud & & FCV -123 & -- & $F$. unknown \\
\hline M. stenostachya & 76 & M-Shoot Bud & 4 & $\begin{array}{l}\text { FC-67, FC-77, FC- } \\
108, \text { FC-109 }\end{array}$ & -- & $\begin{array}{l}F . \text { n. sp.Taylor } 2004 \text { p. } \\
257\end{array}$ \\
\hline M. viridiflora & 77 & M-Shoot Bud & & FC-68, FC-81 & -- & F. burrowsi Taylor 2004 \\
\hline \multicolumn{7}{|l|}{ Syzygium } \\
\hline \multirow[t]{2}{*}{ S. luehmannii } & 78 & Mix of Galls & & FC-734 & -- & $\begin{array}{l}\text { F. n. sp. (Davies et al., } \\
\text { 2014d, pg. 231) }\end{array}$ \\
\hline & 79 & Mix of Galls & & $\begin{array}{l}\text { FC-139, FCV-196, } \\
\text { FCV-200 }\end{array}$ & -- & $\begin{array}{l}F . \text { n. sp. (Davies et al., } \\
\text { 2014d, pg. 231) }\end{array}$ \\
\hline
\end{tabular}

